\title{
Biochemical Evaluation and Maturity Criteria during Fish Waste and Olive Mill Mixed Composting
}

\author{
Mohamed Afifi ${ }^{1}$ and Ahmed Mohy Eldin ${ }^{2}$
}

\author{
${ }^{I}$ Organic Waste Recycling Research Unit., Department of Microbiology, Soils, Water and \\ Environmental Research Institute, Agriculture Research Center (ARC), Giza, Egypt. \\ ${ }^{2}$ Organic Waste Recycling Research Unit., Department of Microbiology, Soils, Water and \\ Environmental Research Institute, Agriculture Research Center (ARC), Giza, Egypt.
}

Received: 25 Dec. 2019 / Accepted 10 Feb. 2020 / Publication date: 15 Mar. 2020

\begin{abstract}
This study introduced two unusual local wastes including fish wastes and olive mill into traditional compost structure of rice straw and cattle dung in permutations and combinations to form three types of heaps (A), (B) and (C). The composting process was investigated following up variable parameters in correlation to enzymatic activities in each heap which was of great feasibility to evaluate heap state. $\mathrm{C} / \mathrm{N}$ ratio, organic matter content and humification parameters were investigated, while the influence of coinciding weathering conditions on temperature and humidity in heaps were evaluated. In their mature state, heavy metal ion concentrations were way down than many worldwide standards and those embedding fish wastes were found to be richer in phosphorous, potassium and zinc, with higher cation exchange capacity. Their germination indices exceeded $70 \%$, while they were all free from parasite, nematodes, total coliforms, fecal coliforms, pathogenic Salmonella and Shigella. They were all compliant to good compost humification parameters, where compost (B) recorded the least humification index $\%$ and humification rate $\%$ while gave the highest humification degree $\%$. Gathering fish waste with equal amounts of olive mill and rice straw in heap (B) made it the best combination constructed for compost production with the highest organic matter $\%$, Nitrogen $\%$, Humification degree $\%$ and germination index among other composts
\end{abstract}

Keywords: compost, fish, olive, weather, enzymes, maturation, humification.

\section{Introduction}

Agricultural and agro-industrial wastes sharing in one harmonically composting process is a big challenge due to their structural variations and unpredictable biological activities when mixed together. Most of organic matter in these wastes can be broken down by various microorganisms whose extracellular hydrolytic enzymes accelerate the process into simpler stable compounds that can be easily assimilated by plants. Tiquia (2005) stated that the evaluations of the composting process, compost maturity and stability were based on physical and chemical parameters of organic material content, reflecting the metabolic activity of micro-organisms involved in the composting process. These parameters include change in compost temperature, phytotoxicity, cation exchange capacity, $\mathrm{C} / \mathrm{N}$ ratio, organic matter and nutrient contents.

Among biological parameters used in evaluation of composting processes are measurable enzymatic activities. A good correlation among enzyme activities and different physiochemical parameters including $\mathrm{C} / \mathrm{N}$ ratio and germination index led to the conclusion that both hydrolytic and dehydrogenase enzyme activities could be feasible indicators of the state and evolution of the composting process.

Usmani et al. (2018) showed that hydrolytic enzymes, due to their inductive nature, were good indicators of quantitative and qualitative changes happening in the content of individual organic polymers in the composting process. Qiao et al. (2019) stated that activities of cellulase, $\beta$-glucosidase and protease exhibited significant correlations with community of microorganisms within the thermophilic and mesophilic phases. As a group of membrane bound enzymes, dehydrogenases play an important role in the metabolic pathways of microbial activities by acting as a catalyst for the synthesis of ATP through oxidative phosphorylation (Barrena et al. 2008). Dehydrogenase activity is the most simple, quick and cheap method used to monitor the maturity and stability of composts

Corresponding Author: Ahmed Mohy Eldin, Department of Microbiology, Soils, Water and Environmental Research Institute, Agriculture Research Center (ARC), Giza, Egypt.

E-mail: ameaefe2006@yahoo.com 
(Azim et al., 2017) and thus is used as an indicator of biological reactions (Saviozzi et al., 2009; Qiao et al., 2019).

Although enzyme activities have been used previously to evaluate the performance of composting, but rarely applied to the marine fish waste composting process for evaluating its state and evolution (Kazemi et al. 2016). During fish wastes composting process, the activities of both oxidoreductase enzyme (as dehydrogenase) and hydrolase enzyme (as $\beta$-glucosidase) are strongly correlated to organic compounds (Kazemi et al., 2017).

In the present study, trials were held to monitor most of previously stated parameters during composting fish wastes and olive mill with other traditional local wastes. The cross correlations between analytical results during and after composting were important in evaluating composting processes and final mature composts. To our knowledge, no study was done on the effect of weather on compost net temperature and moisture, as they were both crucial parameters for the composting process. Many expectations can be deduced based on studies done on the surrounding weather conditions and types of wastes used in heaps to manipulate good composting for minimizing organic matter losses and emissions of greenhouse gases (GHG).

\section{Materials and Methods}

\section{Waste materials}

Locally available waste materials were used in constructing heaps, including air dried and chopped rice straw from local farms, olive mill wastes from olive oil producing factory at Agriculture Research Center - Giza Governorate, fresh fish processing wastes including skin, gills, heads and guts from El- Moneeb fish market, Giza Governorate and fresh cattle dung from cattle farms at faculty of Agriculture, Cairo University.

\section{Heaps construction}

The waste materials were mixed alternatively in a specific manner and stacked in several layers to construct three heaps $\mathrm{A}, \mathrm{B}$ and $\mathrm{C}$ for undergoing composting process. Rice straw was repeatedly included in the three heaps, fish waste in heaps A and B, olive mill in heaps B and C, while cattle dung in heaps A and C. According to their chemical analysis, the ratios of waste materials in mixtures were adjusted for each heap to give total $\mathrm{C} / \mathrm{N}$ ratio of nearly 30 to 35 before composting process. The moisture content in each heap was adjusted to $50-60 \%$ of its water holding capacity. Heaps were overturned efficiently once a week in the first month and once every two weeks until the end of the composting process.

\section{Analysis}

Basic chemical analysis of wastes used were determined before composting process while further chemical, biological and physical determinations for samples from heaps were done during and after composting process. Periodical sampling at $40-60 \mathrm{~cm}$ depth from several spots in each heap was done for the questionable analysis.

\section{Biological determinations:}

Total and fecal coliform bacteria were examined on MacConky agar medium, while Salmonella and Shigella were examined on Bacto-SS agar medium (Difco manual, 1998). Parasites and Nematodes were examined according to Lenore et al. (1998) and Smith (1999). Dehydrogenase activity as TPF $\left[\mu \mathrm{mol} \mathrm{g}^{-1} \mathrm{~h}^{-1}\right.$ ] was assayed by using tri-phenyl tetra-zolium chloride (TTC) method according to Casida et al. (1964). Cellulase activity as glucose $\left[\mu \mathrm{mol} \mathrm{g}^{-1} \mathrm{~h}^{-1}\right]$ was assayed by using filter paper method was done according to Ghose (1987), while the reducing sugar liberated was determined by the method after Miller (1959). Protease activity was qualitatively determined by clear zone test according to modified method of Cowan and Daniel (1982). Phytotoxicity tests for the mature composts were held out by seed germination index (GI\%) technique using water cress seeds (Lepidium sativum L.) as described by Yu et al. (2010). 


$$
\mathrm{GI} \%=\frac{\text { Test }[(\mathrm{GS} \text { no } \div \text { TS no }) \times(\text { TR length } \div \text { GS no })]}{\text { Control }[(\mathrm{GS} \text { no } \div \text { TS no }) \times(\text { TR length } \div \text { GS no })]} \times 100
$$

Where: GI\% (germination index), GS (germinating seeds), TS (total seeds), TR (total root), no (number).

\section{Physical and chemical determination:}

Moisture content (H \%) and dry weight (dwt \%) were determined according to Jackson (1973). Organic matter (O.M) and organic carbon (O.C) were determined according to Cuniff (1995). The $\mathrm{pH}$ values, EC $\left(\mathrm{dSm}^{-1}\right)$ and $\mathrm{T}^{\circ} \mathrm{C}$ were measured according to APHA (1989). Total nitrogen (T.N) and soluble nitrogen $\left(\mathrm{NH}_{3}\right.$ and $\left.\mathrm{NO}_{3}\right)$ were determined according to Jackson (1973).

$$
\begin{aligned}
& \text { OM loss } \%=\frac{\left(\mathrm{OM}_{\text {initial }}-\mathrm{OM}_{\text {final }}\right)}{\mathrm{OM}_{\text {initial }}} \times 100 \\
& \text { OM decomposition rate }=\frac{\left(\mathrm{OM}_{1}-\mathrm{OM}_{0}\right)}{\left(\mathrm{T}_{1}-\mathrm{T}_{0}\right)}
\end{aligned}
$$

Where OM is the organic matter in the sample $\left(\mathrm{kg} \mathrm{heap}^{-1}\right)$; initial and final are the samples taken at the beginning and the end of composting process; $T_{0}$ and $T_{1}$ is the time at which sample $\mathrm{OM}_{0}$ and $\mathrm{OM}_{1}$ was taken (day) in two successive periods.

$$
\begin{aligned}
& \mathrm{C} / \mathrm{N} \text { decrease rate }=\frac{(\mathrm{C} / \mathrm{N})_{1}-(\mathrm{C} / \mathrm{N})_{0}}{\mathrm{~T}_{1}-\mathrm{T}_{0}} \\
& \mathrm{C} / \mathrm{N} \text { loss } \%=\frac{\left(\mathrm{C} / \mathrm{N}_{\text {initial }}-\mathrm{C} / \mathrm{N}_{\text {final }}\right)}{\mathrm{C} / \mathrm{N}_{\text {initial }}} \times 100 \\
& \mathrm{C} \text { loss rate }=\frac{\mathrm{C}_{1}-\mathrm{C}_{0}}{\mathrm{~T}_{1}-\mathrm{T}_{0}} \\
& \mathrm{~N} \text { loss rate }=\frac{\mathrm{N}_{1}-\mathrm{N}_{0}}{\mathrm{~T}_{1}-\mathrm{T}_{0}} \\
& \mathrm{NH}_{4}^{+} \cdot \mathrm{N} \text { loss rate }=\frac{\left.\left(\mathrm{NH}_{4}^{+} \cdot \mathrm{N}\right)_{1}-\mathrm{NH}_{4}^{+} \cdot \mathrm{N}\right)_{0}}{\mathrm{~T}_{1}-\mathrm{T}_{0}} \\
& \mathrm{NO}_{3}^{-} \cdot \mathrm{N} \text { loss rate }=\frac{\left(\mathrm{NO}_{3}^{-} \cdot \mathrm{N}\right)_{1}-\left(\mathrm{NO}_{3}^{-} \cdot \mathrm{N}\right)_{0}}{\mathrm{~T}_{1}-\mathrm{T}_{0}}
\end{aligned}
$$

Where C:N ratios $\left[(\mathrm{C} / \mathrm{N})_{0}\right.$ and $\left.(\mathrm{C} / \mathrm{N})_{1}\right]$; total carbon $(\mathrm{kg} / \mathrm{heap})\left[\mathrm{C}_{0}\right.$ and $\left.\mathrm{C}_{1}\right]$; total nitrogen $\left(\mathrm{kg} /\right.$ heap) $\left[\mathrm{N}_{0}\right.$ and $\left.\mathrm{N}_{1}\right]$; ammonium nitrogen $(\mathrm{ppm})\left[\left(\mathrm{NH}_{4}{ }^{+} . \mathrm{N}\right)_{0}\right.$ and $\left.\left(\mathrm{NH}_{4}{ }^{+} . \mathrm{N}\right)_{1}\right]$ and nitrate nitrogen $(\mathrm{ppm})\left[\left(\mathrm{NO}_{3}{ }^{-} . \mathrm{N}\right)_{0}\right.$ and $\left.\left(\mathrm{NO}_{3}{ }^{-} \mathrm{N}\right)_{1}\right]$ are concentrations in two successive periods $\mathrm{T}_{0}$ and $\mathrm{T}_{1}$, respectively.

Total phosphorus in the acid digest was determined by the method of Murphy and Riley (1962). Potassium was determined in the same digest by flame photometry according to the method of Chapman and Pratt (1961). The concentrations of heavy metals (mg/kg dry weight) including Chromium, Cadmium, Copper, Nickel, Lead, Manganese and Zinc in sample digest were determined by inductively coupled plasma spectrometry (ICP) (Ultima 2 JY Plasma). Recommended sample digestion using nitric acid modified procedure was followed after Hseu (2004). The worldwide standards for heavy metals maximum allowed concentrations were compared to final compost content as mentioned by Hogg et al. (2002).

Cation exchange capacity (CEC) was determined using ammonium acetate substitution method according to Schollenberger and Simon (1945). The concentration of ammonium nitrogen $\left(\mathrm{NH}_{4}-\mathrm{N}\right)$ in the final leachate was determined using the Kjeldahl distillation method according to Jackson (1973). 


$$
\operatorname{CEC}\left(\frac{\mathrm{meq}}{100 \mathrm{~g}}\right)=\left(\mathrm{mg} \mathrm{NH}_{4}^{+} . \mathrm{N} / \mathrm{L} \text { leachate }\right) \times \frac{0.25}{14} \times \frac{100}{\text { Sample size }(\mathrm{g})}
$$

Humic and fulvic extraction was performed based on the method of Duchaufour and Jacquin (1966) and according to Schnitzer (1982). Sodium hydroxide was replaced by potassium hydroxide for better extraction efficiency and quality according to Afifi (2010). The humification parameters in compost were calculated according to Ciavatta et al. (1990b) as follows:

$$
\begin{gathered}
\text { Humification rate }(\mathrm{HR} \%)=\frac{\mathrm{C}_{\mathrm{HA}}+\mathrm{C}_{\mathrm{FA}}}{\mathrm{TOC}} \times 100 \\
\text { Humification degree }(\mathrm{HD} \%)=\frac{\mathrm{C}_{\mathrm{HA}}+\mathrm{C}_{\mathrm{FA}}}{\mathrm{TEC}} \times 100
\end{gathered}
$$

Where: $\mathbf{C}_{\mathbf{H A}}$ (Humic acid carbon), $\mathbf{C}_{\mathbf{F A}}$ (Fulvic acid carbon), TOC (Total organic carbon).

$$
\text { Humification index }(\mathrm{HI})=\frac{\mathrm{TEC}-\left(\mathrm{C}_{\mathrm{HA}}+\mathrm{C}_{\mathrm{FA}}\right)}{\mathrm{C}_{\mathrm{HA}}+\mathrm{C}_{\mathrm{FA}}}
$$

Where: TEC (Total extractable carbon), \{TEC - $\left.\left(\mathbf{C}_{\mathbf{H A}}+\mathbf{C}_{\mathbf{F A}}\right)\right\}$ represents non-humified fractions, while $\left\{\mathbf{C}_{\mathbf{H A}}+\mathbf{C}_{\mathbf{F A}}\right\}$ represents the humified compounds.

\section{Weather measurements}

Air humidity, temperature, precipitation and wind speed measures were based on the archive of Cairo airport weather forecast (HECA) compared to supplementary data from https:/www.worldweatheronline.com/gizeh-weather-history/al-jizah/eg.aspx .

\section{Statistical analysis}

Results data were accomplished in triplicates and statistically evaluated by least significant difference (LSD) in one-way analysis of variance (ANOVA) through Ducan's Multiple Range test at significance level of 5\% calculated using CoHort software under windows (Costat, model 6.311) as mentioned by Rosner (2006). The standard errors based on standard deviations, graphic presentations and Pearson's correlation coefficients were all done using Excel program software (Microsoft office 2010).

\section{Results and Discussion}

\section{Waste materials, chemical analysis and heaps constructions:}

In a preliminary step, the analysis of materials used in formation of the three heaps was crucial to maintain proper carbon to nitrogen ratio as shown in Figure (1). The waste materials used were rice straw, olive mill, cattle dung and fish wastes with [C/N, dwt\%] of [65:1, 90\%], [57:1, 94\%], [20:1, $39 \%]$ and $[13: 1,1 \%]$, respectively. The heaps A, B and C constructed from those wastes had C: N ratios of $32.3,32.2$ and 28.6 , respectively.

The initial $\mathrm{C}$ : $\mathrm{N}$ ratio range from 25-35:1 was ideal as it was found to enhance composting efficiencies (Bishop and Godfrey, 1983; Qiao et al., 2019). Pace et al. (1995) found that bacteria, actinomycetes, and fungi required carbon and nitrogen for growth using 30 parts of carbon to 1 part of nitrogen. On those bases the heap constructions fell in the ideal range of $\mathrm{C}: \mathrm{N}$ ratio 25-35:1.

\section{Heap temperature and humidity influenced by ambient weather variations:}

In regard to weather conditions during composting period illustrated in Figure (2), the temperatures in the three heaps were affected variably by weather parameters including temperature, wind speed and humidity, either individually or collectively. 


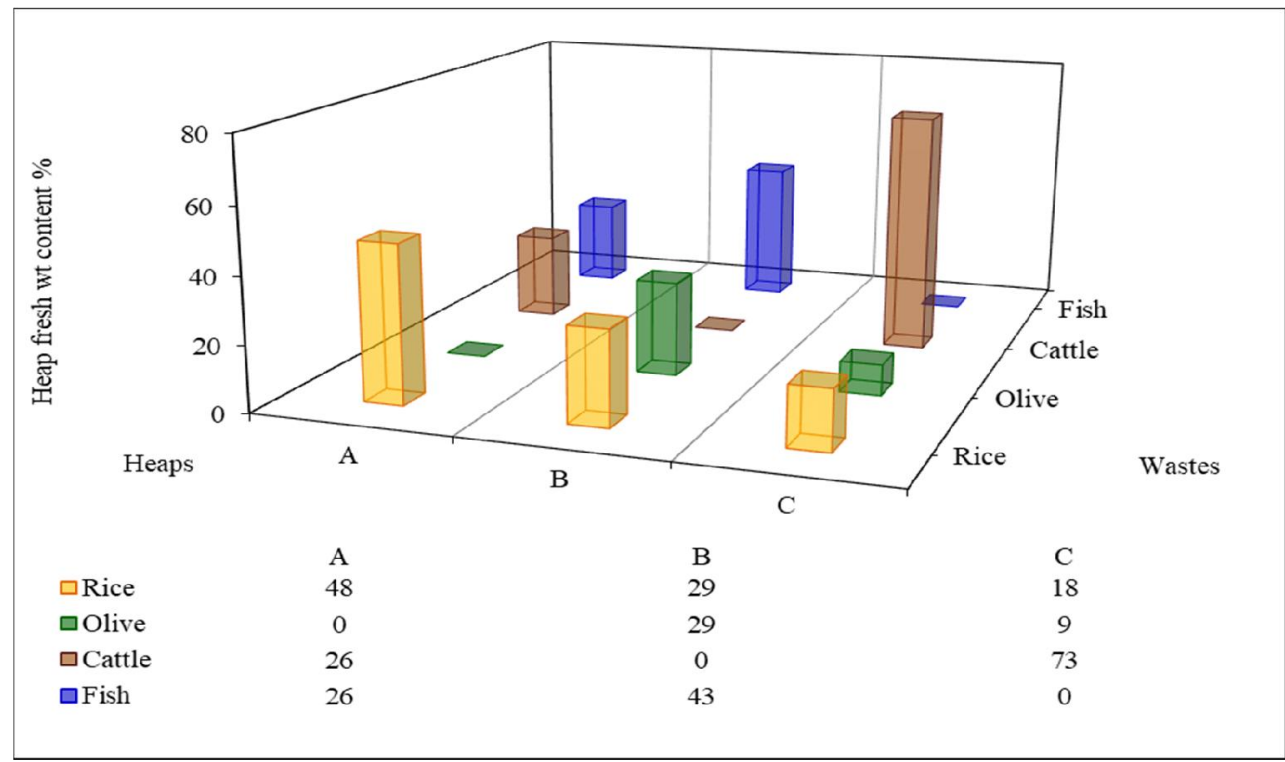

Fig. 1: Constructing three heaps from different fresh waste materials before composting process.

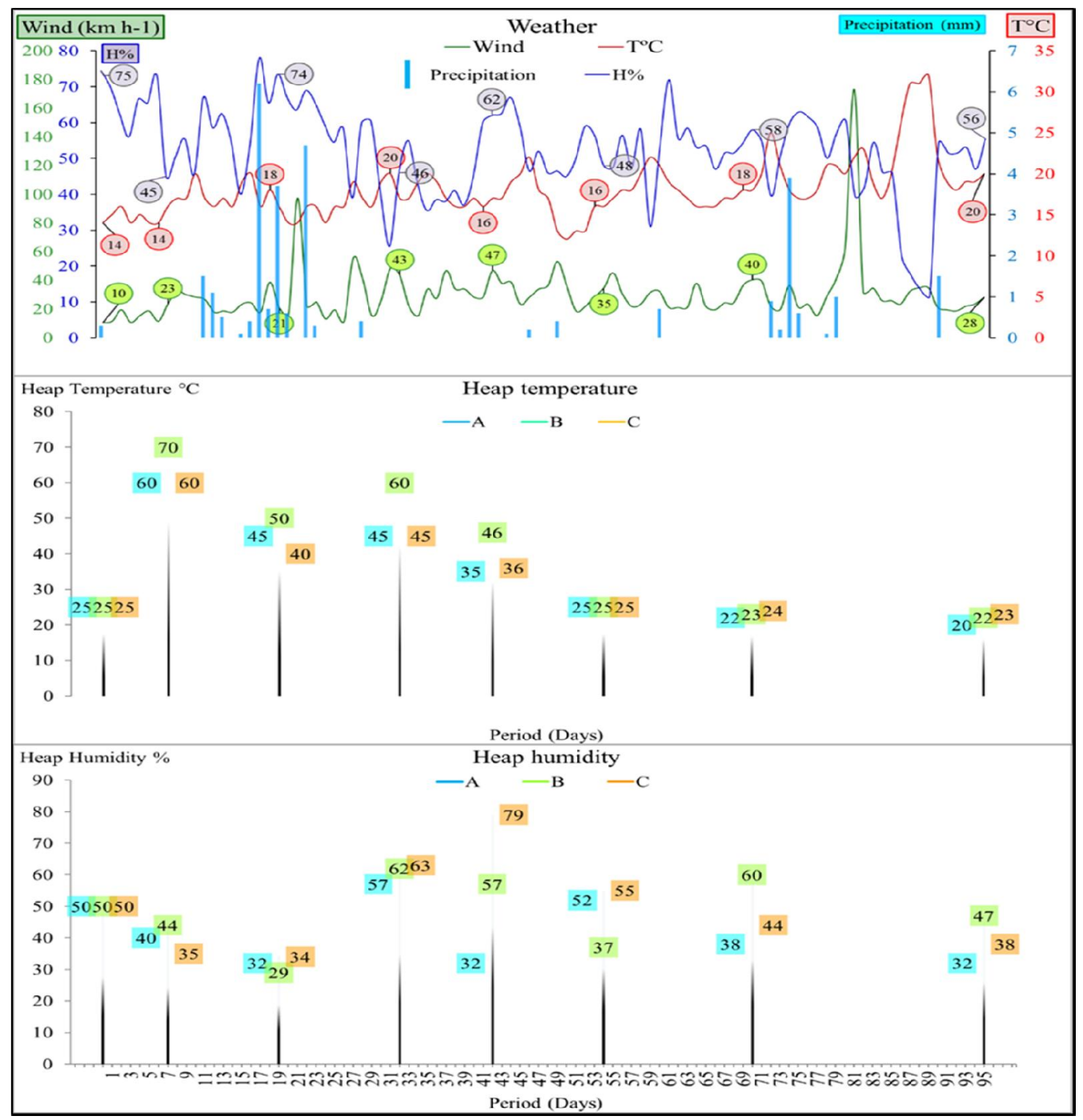

Fig. 2: Indirect effects of weather conditions on heap temperature and humidity. 
During the first week of composting, average weather temperature recorded $15 \pm 1^{\circ} \mathrm{C}$, weather humidity was fluctuating to record $69 \pm 6 \%$, while average wind speed was $14 \mathrm{~km} \mathrm{~h}^{-1}$ after which the temperatures in heaps $\mathrm{A}, \mathrm{B}$ and $\mathrm{C}$ recorded as high as 60,70 and $60^{\circ} \mathrm{C}$.

Afterwards up to day 19 the average wind speed increased up to $32 \mathrm{~km} \mathrm{~h}^{-1}$, gathered with weather temperature of $18^{\circ} \mathrm{C}$, precipitation and humidity of $51 \%$ gave a collective cooling effect at the surface of the heaps, that apparently had an partial role in decreasing recorded temperatures in heaps A, B and $\mathrm{C}$ at day 19 down to 45,60 and $45^{\circ} \mathrm{C}$, respectively. Similarly, Tiquia, (2005) and Barrena et al. (2008) stated that the highest temperature recorded during composting was $70^{\circ} \mathrm{C}$ at the beginning of thermophilic stage.

According to Pearson correlations in the thermophilic stages shown in Figure (3), the strong effect of both weather temperatures $(+0.7)$ and humidity $(-0.7 /-0.8)$ on temperatures in all heaps were in agree with that deduced previously from Figure (2). In spite of the individual positive effect of wind speed $(+0.4 /+0.5)$ on temperatures in all heaps during their thermophilic stages, as it was known to aide drying humidity at heap surface but it was complementary to the effect of high weather humidity as it possibly increased the final surface cooling effect that could have the upper hand in decreasing temperatures in heaps. In the mesophilic stages, weather temperature was negatively correlated to temperatures in all heaps to be stronger in heap B, while wind speed was positively correlated to temperatures in heaps to be weaker in heap B.

Negative correlations were dominant between heap moisture and temperature in both thermal stages in all heaps, except for heap $\mathrm{C}$ where correlation was strongly positive in its mesophilic stage, as shown in Figure (4). To explain this, Finstein et al. (1986) stated that during aerobic composting, 1 $\mathrm{g}$ of organic matter released about $25 \mathrm{~kJ}$ of heat energy, which was enough to vaporize $10.2 \mathrm{~g}$ of water. Naylor (1996) explained that this vaporization will be further coupled with losses due to aeration leading to more moisture loss during composting. This explained the drop in humidity of heaps after 7 days as temperatures in heaps increased to their maximum $\geq 60^{\circ} \mathrm{C}$ at the beginning of thermophilic stage (negative correlation).

After 19 days, humidity in heaps recorded lower than $35 \%$ accompanied with drop in their temperatures $\leq 50^{\circ} \mathrm{C}$. This phenomenon was previously explained by Cooperband (2002) who pointed out that moisture level below $45 \%$ pushed composting heap to heat up and cool down more quickly. Besides, Young et al. (2005) stated that if the moisture content decreased below 30\%-35\% it caused a marked reduction in the microbiological activity and the rate of decomposition decreased rapidly. Thus, any decrease recognized in humidity due to rise in temperature will be followed by reduction in microbial activities and consequently decrease in temperature.

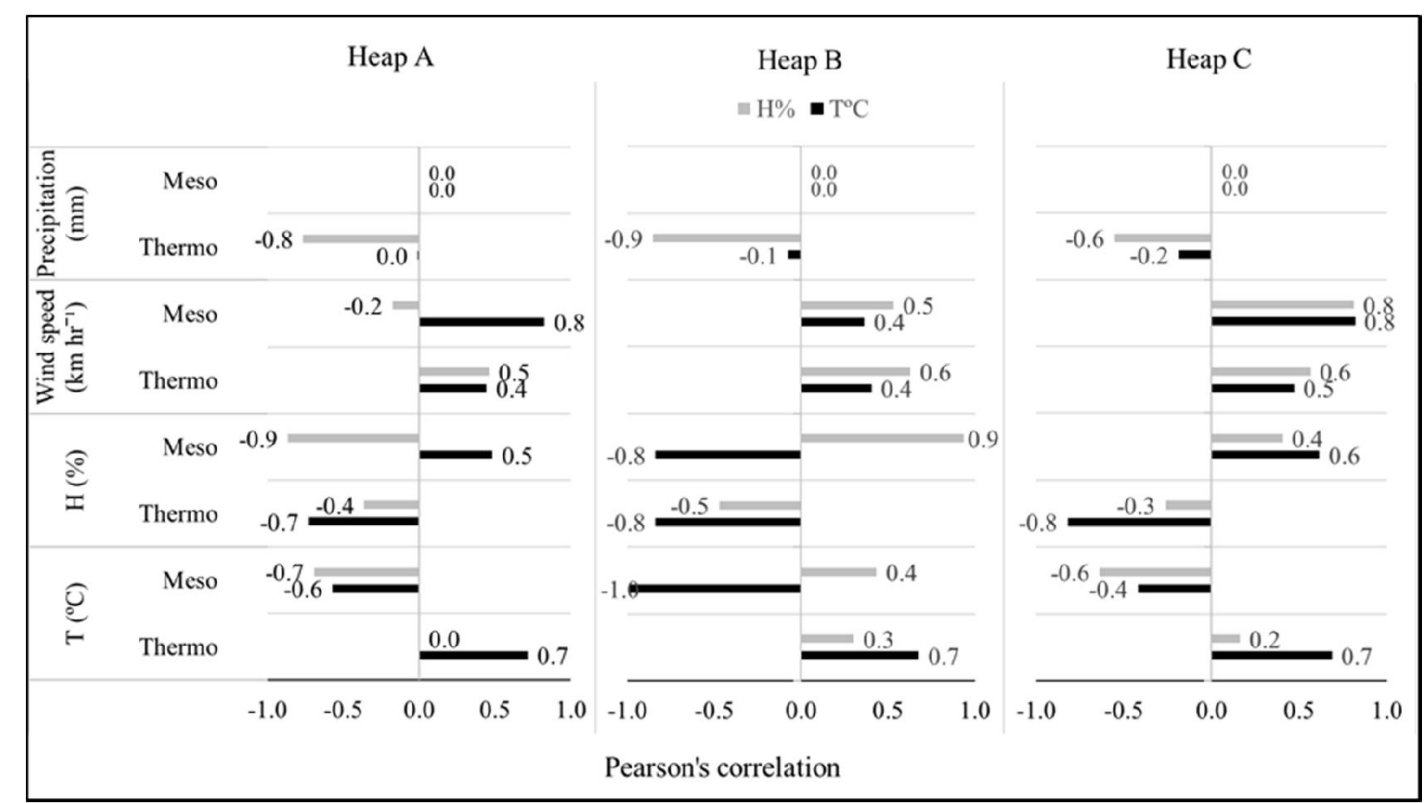

Fig. 3: Weather temperature, humidity, wind and precipitation correlated to temperature and humidity in the three heaps during composting stages. 


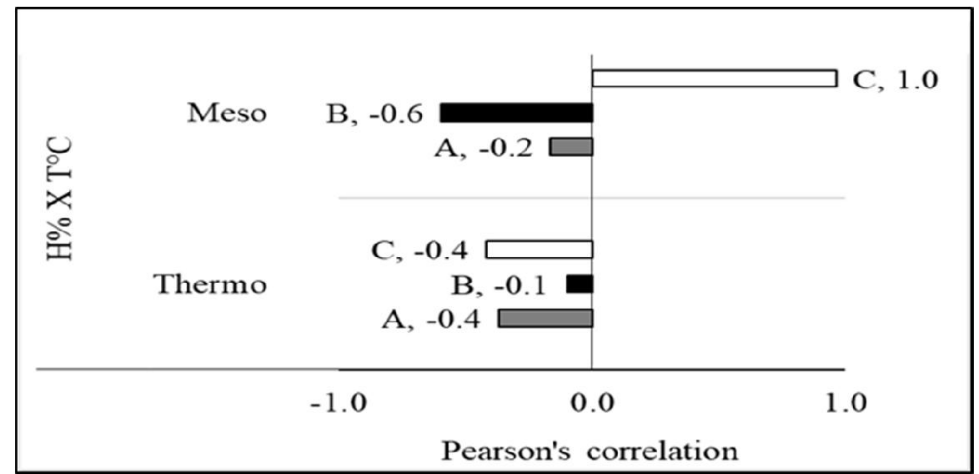

Fig. 4: Correlation between heap temperature and its humidity in accordance with thermal stages.

Added to that, Das and Keener (1997) and Young et al. (2005) stated that if moisture exceeded $60 \%$, the structural strength of the compost deteriorated, will prevent oxygen diffusion to the organisms and the process tended to be anaerobic. This might explain case within heaps A, B and C near the end of their thermophilic stages where humidity recorded 57\% (day 32), 62 (day 32)-57 (day 42 ) and 63 (day 32)-79\% (day 42), as the period following the rise in their humidity recorded a remarkable drop in their temperatures by $10^{\circ} \mathrm{C}$ (day 42 ), $10^{\circ} \mathrm{C}$ (days 42 and 54) and $9^{\circ} \mathrm{C}$ (days 42 and 54), respectively. Added to that, the possibility of decrease in metabolic activities for microorganisms responsible for degradation of complex structures in the thermophilic stage where compost temperatures weren't enough to cause vaporization in their moisture. That is why moisture is a crucial factor controlling compost temperature to be ideal (it should be maintained at 45-60\%) (Gajalakshmi and Abbasi, 2008)

\section{3. $\mathrm{pH}$ and $\mathrm{EC}$ values during composting:}

The recorded $\mathrm{pH}$ values in all heaps decreased from above 8 (colored blue) down to $7 \pm 0.1$ (colored green), with an occasional drop in $\mathrm{pH}$ (colored red) below 7 recording 6.3 in heap B at the end of its thermophilic stage (day42), as illustrated in Figure (5). Approaching stable maturity, $\mathrm{pH}$ values became more stable near $7 \pm 0.1$ in the three heaps after 70 days in heaps (A) and (B), while it was stable after 54 days in heap (C).

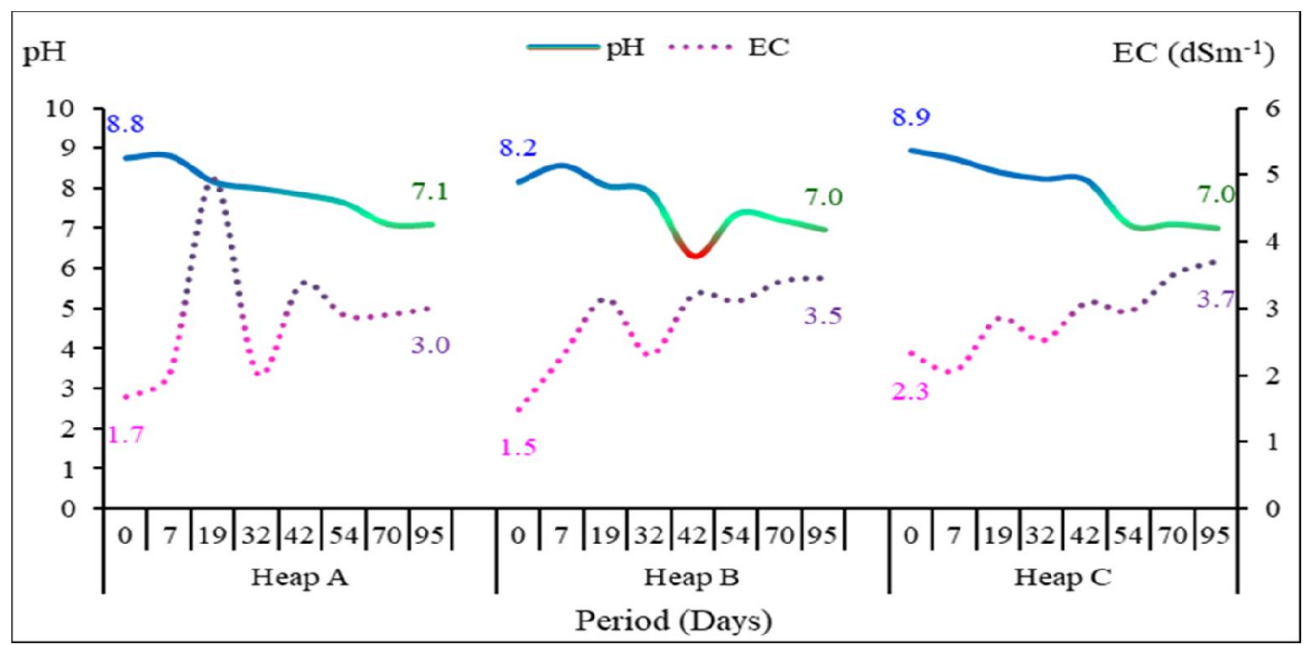

Fig. 5: $\mathrm{pH}$ and EC values measured periodically during composting process in the three heaps.

Muktadirul et al. (2013) stated that the acidic nature of olive mill waste affects the initial $\mathrm{pH}$ value of the composting mixture. That was why heap B containing more olive wastes than heap $\mathrm{C}$ had lower initial $\mathrm{pH}$ value of 8.2. The gradual drop in $\mathrm{pH}$ values during composting process happened all over the three heaps. Mustin (1987) found that in the early stage of composting, both bacteria and fungi acting on organic matter released organic acids that accumulated causing drop in $\mathrm{pH}$ values. 
This drop in $\mathrm{pH}$ favored the growth of fungi and the breakdown of lignin and cellulose (Paredes et al., 1999).

The $\mathrm{pH}$ value fluctuation was a net result from metabolites of which organic acids causing acidity and ammonia causing alkalinity played their roles as explained by Gigliotti et al. (2012). In this regard, Azim et al., (2017) stated that at the very beginning of thermophilic stage, microorganisms degraded proteins and ammonia was released causing temporary rise in $\mathrm{pH}$ values before it dropped due to degradation of carbohydrates and lipids that released organic acids, even after temperature approached $70^{\circ} \mathrm{C}$ as the enzymes that had been previously released continued their actions. This explained clearly in the present work the slight rise in $\mathrm{pH}$ values at day 7 in both heaps $\mathrm{A}$ and $\mathrm{B}$ followed by drop in its values afterwards up till the end of composting period. Worthy to mention the strong positive correlation between $\mathrm{pH}$ values and $\mathrm{T}^{\circ} \mathrm{C}$ in all heaps during their mesophilic stages that was more relevant than in thermophilic stage where correlations were weaker, as illustrated in Figure (6).

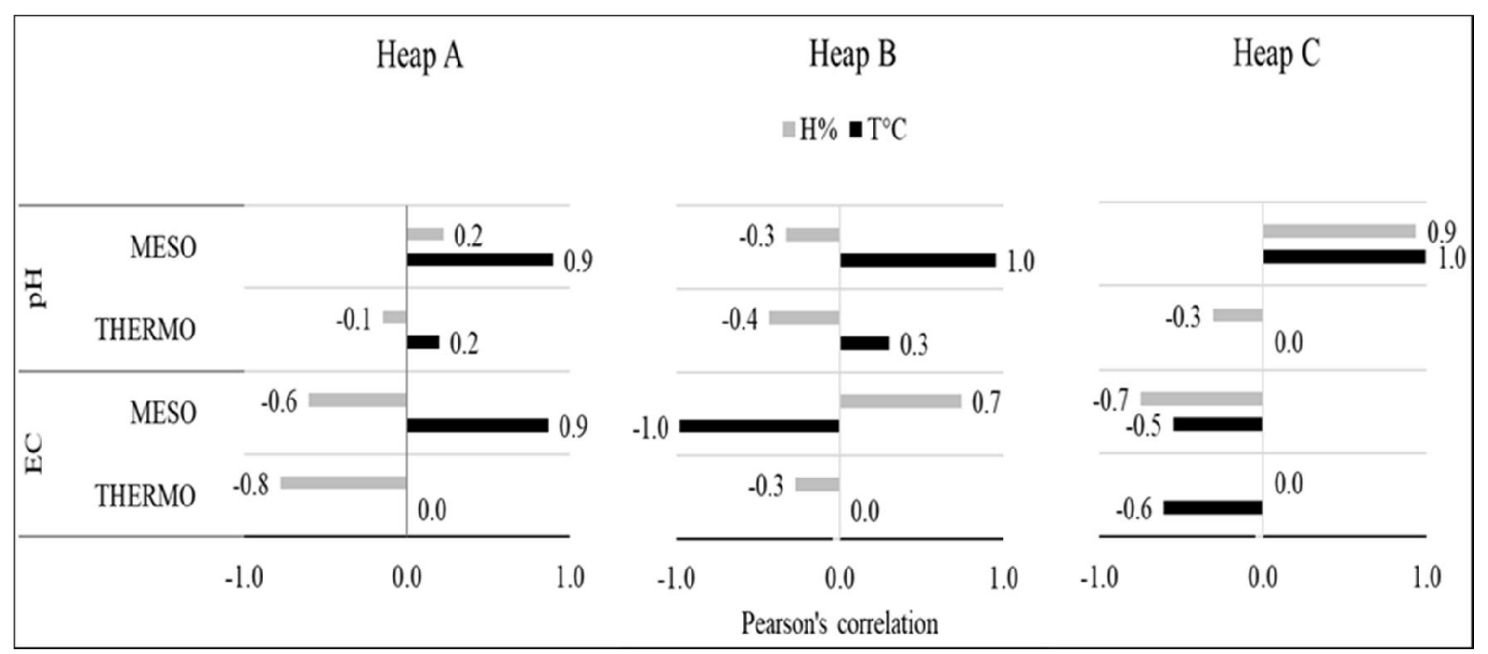

Fig. 6: Pearson's correlation between temperature and humidity in heaps against their $\mathrm{pH}$ and $\mathrm{EC}$ values.

On the contrary, the EC values in the three heaps $\mathrm{A}, \mathrm{B}$ and $\mathrm{C}$ increased throughout their composting period recording initial to final values of 1.7 to $3.00,1.5$ to 3.5 and 2.3 to 3.7 , respectively. The increase was fluctuating as it was interrupted by sever rise recorded at day 19 in heap A than heaps B and C followed by drop at day 32 afterwards. Worthy to notice that this fluctuation happened parallel to the drop in temperature for the three heaps at day 19 and regained rising at day 32 as illustrated before in Figure (2). EC values usually increased at the end of composting due to decrease in compost total mass (Gigliotti et al., 2012) and due to evaporation of heap moisture as observed before by Baeta-Hall et al. (2005), but in some cases it may decrease (drop) during composting period due to losing of minerals by leaching (Said-Pullicino and Gigliotti, 2007).

\section{Heap organic content analysis (OM., $\left.\mathrm{C}, \mathrm{N}, \mathrm{NH}_{3}-\mathrm{N}, \mathrm{NO}_{3}-\mathrm{N}\right)$.}

\subsection{Organic matter}

Organic matter content in the three heaps decreased during the composting period recording bigger initial to final losses exceeding $70 \%$ in heaps $\mathrm{A}$ and B containing fish wastes, while in heap C with no fish wastes recorded 53\% loss as shown in Table (1) and illustrated in Figure (7). Worthy to mention that $50 \%$ or more of the organic matter would be lost during composting (Chefetz et al., 1998). 


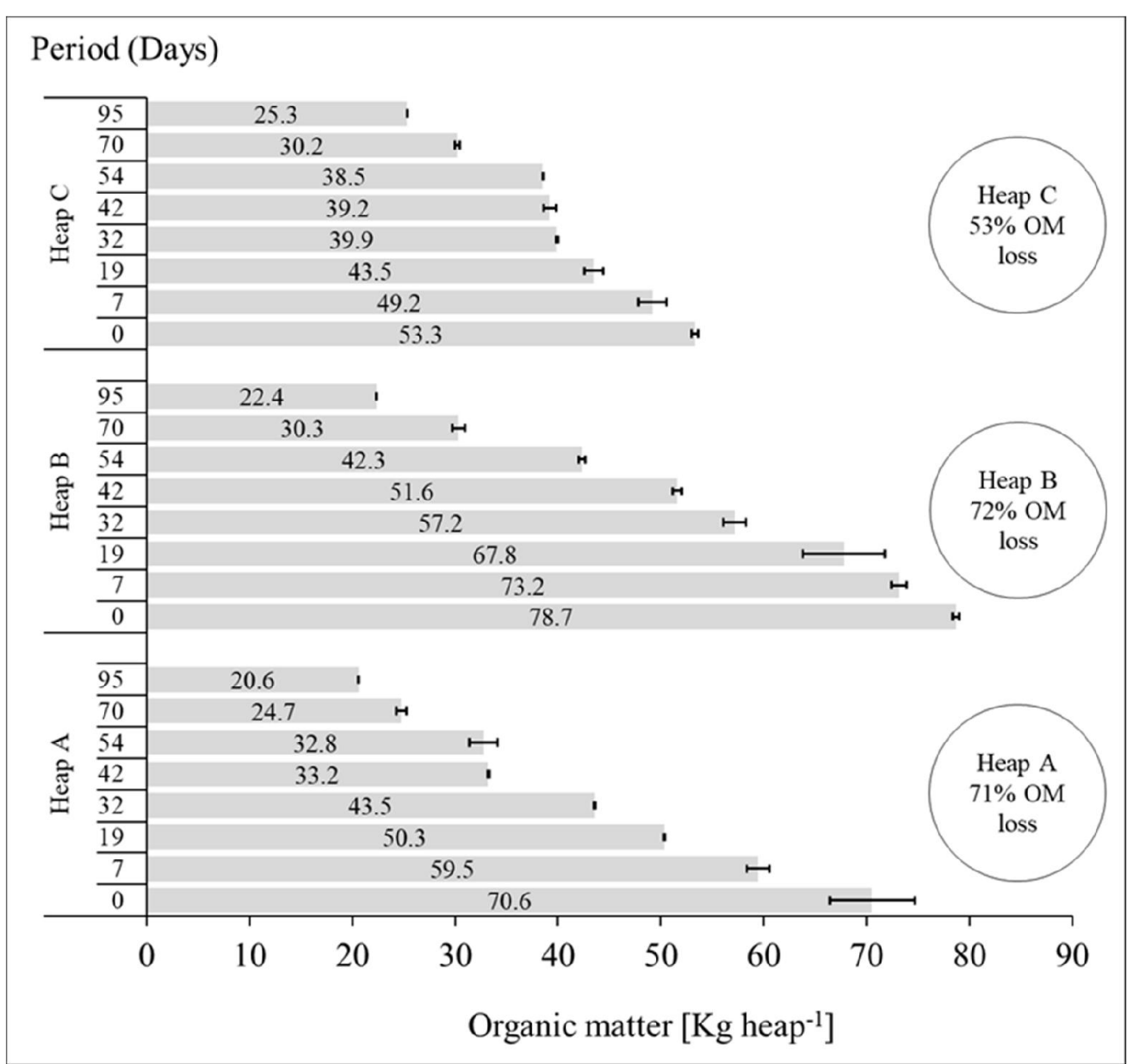

Fig. 7: Organic matter content in each heap during composting period and organic matter loss percentage (circle labels).

Added to that, OM decomposition rates in heap A were higher than in heap B followed by heap $\mathrm{C}$ during their thermophilic stages and through which their maximum records were parallel to the temperature elevation measured, as shown in Figure (8) characterized by with strong positive correlations of +0.8 to +1.0 as shown in Table (1) and illustrated in Figure (9). Later, the decrease of OM decomposition rates in were parallel to the decrease in heaps' temperatures which were affected by loss in $\mathrm{H} \%$ content after recording the highest temperatures of heaps at day 7 as discussed before in Section 2, relevant to negative correlations between $\mathrm{H} \%$ and $\mathrm{OM}$ decomposition rates and putting in consideration the non-parallel fluctuations in $\mathrm{OM}$ decomposition rate and $\mathrm{H} \%$ always result in weak correlations (near zero) as within heap B.

In fact, losing moisture as $\mathrm{H} \%$ by evaporation during thermophilic stages could decrease degradation rate of organic matter and that was why Bernal et al. (2009) insisted on remoistening composting heaps frequently. Added to that, Tortosa et al. (2012) found that compostable wastes of high organic matter concentration prolonged the thermophilic phase, similar to what had happened in heap B containing more organic matter than A and C. 


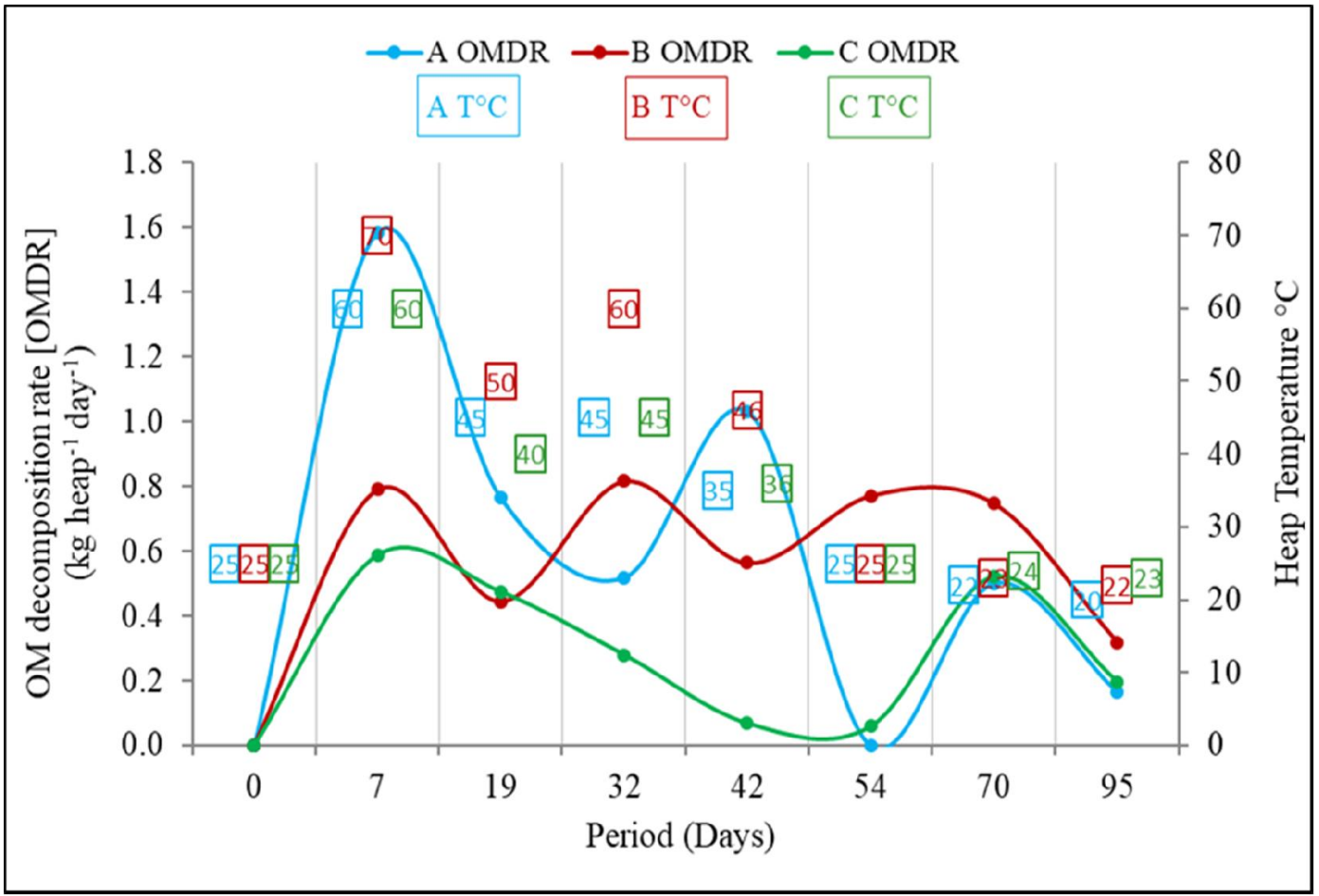

Fig. 8: Organic matter decomposition rate (OMDR) and temperature measured in the three heaps during composting period.

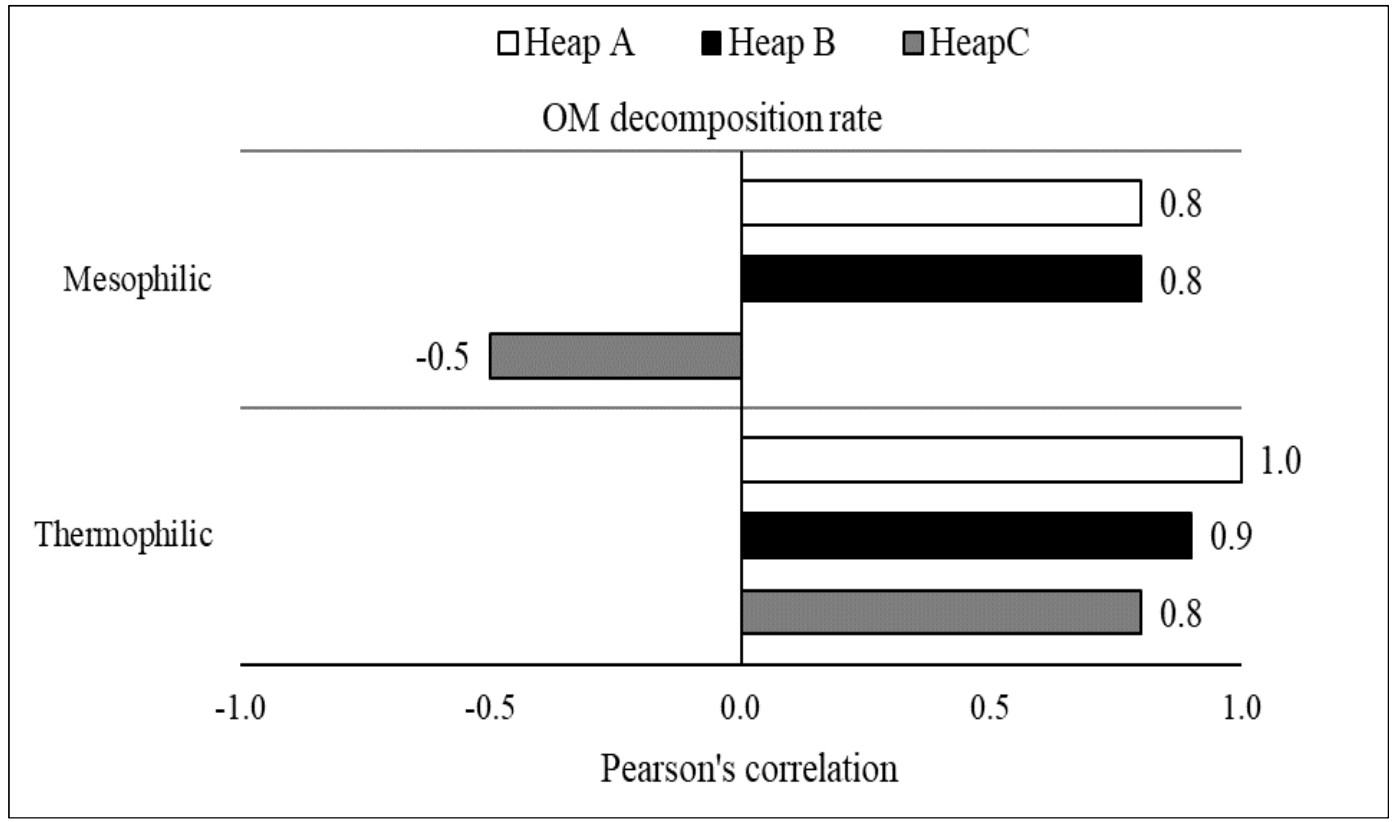

Fig. 9: Pearson' correlation of Organic matter decomposition rate with both $\mathrm{T}^{\circ} \mathrm{C}$ and $\mathrm{H} \%$ in the three heaps in accordance with their thermophilic and mesophilic stages

\section{2. $\mathrm{C} / \mathrm{N}$ ratio fate in the three heaps during composting process}

The carbon and nitrogen criteria in the three heaps A, B and C shown before in Table (1) revealed decrease in their $\mathrm{C} / \mathrm{N}$ ratios in accordance to their temperature variations, as shown in Table (2). 
Table 1: Total dry weight (DW), Organic matter (OM), organic carbon (OC), total nitrogen (TN), $\mathrm{NH}_{4}{ }^{+}-\mathrm{N}$ and $\mathrm{NO}_{3}{ }^{-}-\mathrm{N}$ contents in the three heaps in accordance

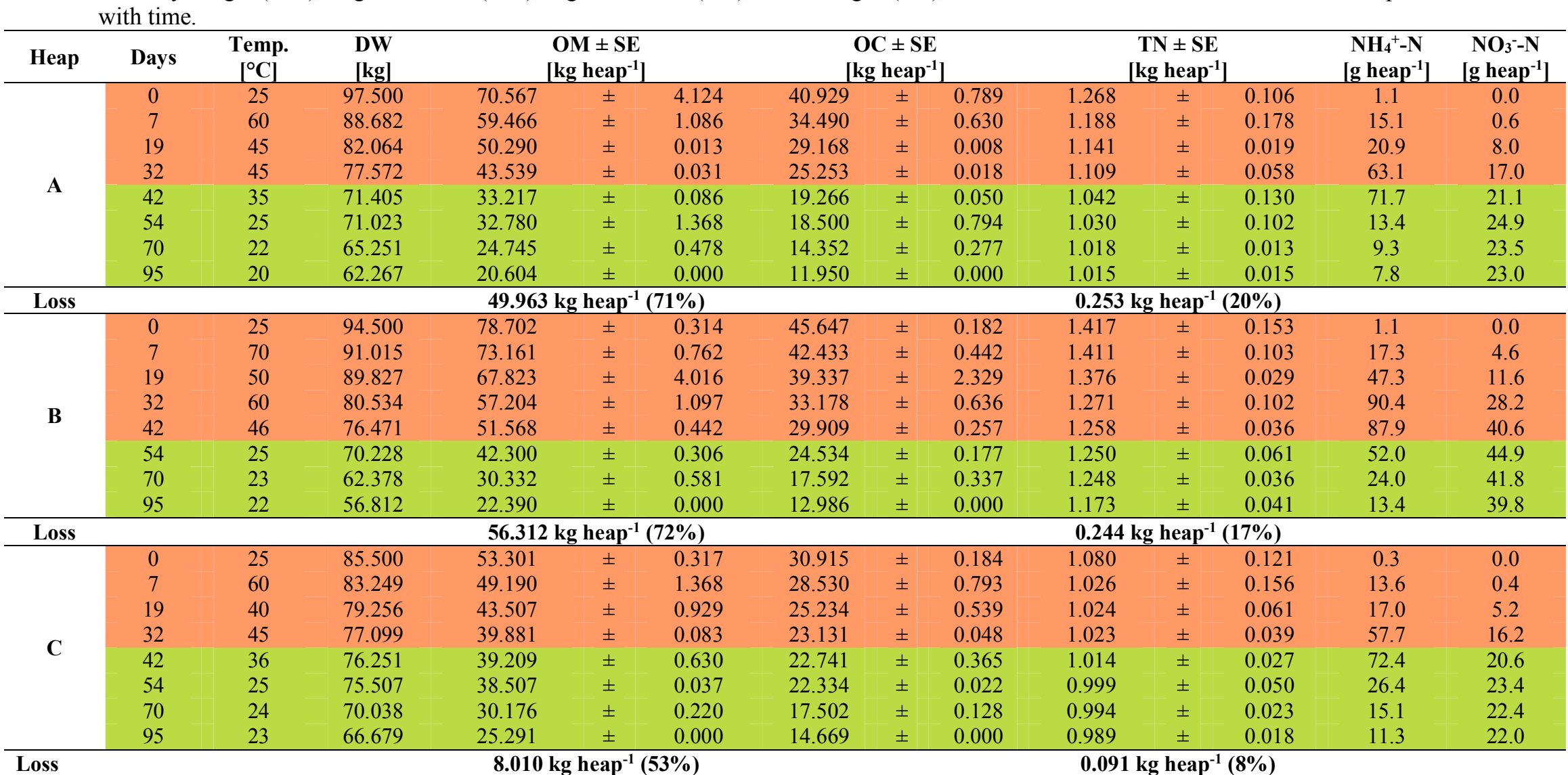


Table 2: $\mathrm{C} / \mathrm{N}$ ratios, $\mathrm{C} / \mathrm{N}$ periodical and daily decrease rates related to periodical heap temperatures in heaps $\mathrm{A}, \mathrm{B}$ and $\mathrm{C}$.

\begin{tabular}{|c|c|c|c|c|c|c|c|c|c|c|c|c|}
\hline \multirow{3}{*}{$\begin{array}{l}\text { Heaps } \\
\begin{array}{c}\text { Period } \\
\text { (Days) }\end{array}\end{array}$} & \multirow[b]{3}{*}{$\mathrm{T}^{\circ} \mathrm{C}$} & \multicolumn{3}{|c|}{$\mathbf{A}$} & \multicolumn{4}{|c|}{ B } & \multicolumn{4}{|c|}{$\mathrm{C}$} \\
\hline & & \multicolumn{3}{|c|}{$\mathbf{C} / \mathbf{N}$} & \multicolumn{4}{|c|}{$\mathbf{C} / \mathbf{N}$} & \multicolumn{4}{|c|}{$\mathbf{C} / \mathbf{N}$} \\
\hline & & Ratio & $\begin{array}{c}\text { Decrease } \\
\text { (period) }\end{array}$ & $\begin{array}{c}\text { decrease } \\
\text { rate } \mathrm{T} \\
{ }^{\circ} \mathrm{C} \text { (day) }\end{array}$ & $\begin{array}{c}\mathrm{T} \\
{ }^{0} \mathrm{C}\end{array}$ & Ratio & $\begin{array}{c}\text { Decrease } \\
\text { (period) }\end{array}$ & $\begin{array}{c}\text { Decrease } \\
\text { rate } \\
\text { (day) }\end{array}$ & $\underset{ }{\mathrm{T}}$ & Ratio & $\begin{array}{c}\text { Decrease } \\
\text { (period) }\end{array}$ & $\begin{array}{c}\text { Decrease } \\
\text { rate } \\
\text { (day) }\end{array}$ \\
\hline $\mathbf{0}$ & 35 & 32.3 & 0.0 & 0.0 & 35 & 32.2 & 0.0 & 0.0 & 35 & 28.6 & 0.0 & 0.0 \\
\hline 7 & 60 & 29.0 & -3.3 & -0.5 & 70 & 30.1 & -2.1 & -0.3 & 60 & 27.8 & -0.8 & -0.1 \\
\hline 19 & 45 & 25.6 & -3.5 & -0.3 & 42 & 28.6 & -1.5 & -0.1 & 40 & 24.6 & -3.2 & -0.3 \\
\hline 32 & 45 & 22.8 & -2.8 & -0.2 & 60 & 26.1 & -2.5 & -0.2 & 45 & 22.6 & -2.0 & -0.2 \\
\hline 42 & 35 & 18.5 & -4.3 & -0.1 & 46 & 23.8 & -2.3 & -0.2 & 36 & 22.4 & -0.2 & 0.0 \\
\hline 54 & 25 & 18.0 & -0.5 & 0.0 & 25 & 19.6 & -4.2 & -03 & 25 & 22.4 & -0.1 & 0.0 \\
\hline 70 & 22 & 14.1 & -3.9 & -0.2 & 23 & 14.1 & -5.5 & -0.3 & 24 & 17.6 & -4.7 & -0.3 \\
\hline 95 & 20 & 11.8 & -2.3 & -0.1 & 22 & 11.1 & -3.0 & -0.1 & 23 & 14.8 & -2.8 & -0.1 \\
\hline \multicolumn{2}{|c|}{$\mathrm{C} / \mathrm{N} \operatorname{loss} \%$} & \multicolumn{3}{|c|}{63.5 (heap A) } & \multicolumn{4}{|c|}{65.6 (heap B) } & \multicolumn{4}{|c|}{$48.2($ heap C) } \\
\hline \multicolumn{13}{|c|}{ Correlation between $\mathrm{OM}$ decomposition rate and $\mathrm{C} / \mathrm{N}$ change rate } \\
\hline & & \multicolumn{3}{|c|}{-1.0 (heap A) } & \multicolumn{4}{|c|}{-0.9 (heap A) } & \multicolumn{4}{|c|}{-0.8 (heap C) } \\
\hline
\end{tabular}

Daily decrease rate in $\mathrm{C} / \mathrm{N}$ remarkably slowed down in heaps $\mathrm{A}$ and $\mathrm{C}$ making $\mathrm{C} / \mathrm{N}$ nearly more stable for two successive periods [42 and 54 days] coinciding with the beginning of their mesophilic stages. On the other hand, the $\mathrm{C} / \mathrm{N}$ decrease rate was higher in heaps $\mathrm{A}$ and $\mathrm{B}$ (containing fish wastes) at the beginning of their thermophilic stages and mesophilic stages. The $\mathrm{C} / \mathrm{N}$ decrease rates in all heaps were negatively correlated to OM decomposition rate dependent on its loss. Pace et al. (1995) stated that the rate of composting had decreased as the $\mathrm{C}: \mathrm{N}$ ratio had exceeded 30. Similarly, from results shown previously in figure (5), the organic matter decomposition rate [as a proof for composting rate] was higher in Heap $\mathrm{A}>\mathrm{B}>\mathrm{C}$ on day 7 in accordance to their initial $\mathrm{C}: \mathrm{N}$ ratios.

Added to that, Chefetz et al. (1998) stated that during composting nearly $50 \%$ of the organic matter would be fully mineralized, producing $\mathrm{CO}_{2}$ and water. Also, Hamoda et al. (1998) stated that during composting the bioconversions reduced carbon and increased nitrogen concentrations due to loss in total dry mass as it lost carbon in the form of $\mathrm{CO}_{2}$. The loss in $\mathrm{C}$ content might be in the only two possible forms including $\mathrm{CO}_{2}$ or methane $\mathrm{CH}_{4}$ correlated to moisture content in each heap, sharing in greenhouse gases (GHG) as stated before by Park et al. (2017) and this might explain possible forms of $\mathrm{C}$ loss during OM decomposition in heaps $\mathrm{A}, \mathrm{B}$ and $\mathrm{C}$ especially at the 32 days period when humidity near the end of their thermophilic stages and the beginning of their mesophilic stages recorded $57 \%$ in heap A, 62-57\% in heap B and $63-79 \%$ in heap C, as previously shown before in Figure (2). The initial to final losses of $\mathrm{C} / \mathrm{N}$ ratio in heaps $\mathrm{A}$ and $\mathrm{B}$ were bigger than in heap $\mathrm{C}$ as shown in Table (2) and were found to be parallel to their OM loss \% previously illustrated in Figure (7).

\subsection{Nitrogen forms and concentrations in heaps during composting:}

The nitrogen concentrations as total $\mathrm{N}$, ammonium and nitrate previously shown in Table (1) variably changed relative to composting number of days illustrated as change rates in Figure (10).

In the thermophilic stage, the change rate in $\mathrm{NH}_{4}{ }^{+}-\mathrm{N}$ correlated to total $\mathrm{N}$ was negative but was positively correlated to $\mathrm{NO}_{3}^{-}-\mathrm{N}$ in all heaps, proving that any decrease in total nitrogen during composting was accompanied by rise in $\mathrm{NH}_{4}^{+}$formation followed by rise in $\mathrm{NO}_{3}^{-}$formation too. Nitrogen metabolism was associated with ammonia volatilization as a result of ammonification activities by microorganisms from the beginning of the composting process as stated by Bohacz, J. (2019).

This $\mathrm{NH}_{4}^{+}$release had been explained before by Gigliotti et al. (2012) who stated that as composting progressed to thermophilic stage and due to aerobic conditions caused by mechanical turning of the heaps; microbial metabolic action on proteins, peptides and amino acids released $\mathrm{NH}_{4}{ }^{+}$. In the present study, the transformation of released $\mathrm{NH}_{4}{ }^{+}$into $\mathrm{NO}_{3}{ }^{-}$continued in the mesophilic stages in which the decrease in released $\mathrm{NH}_{4}{ }^{+}$was followed by instant transformation to $\mathrm{NO}_{3}{ }^{-}$giving their correlation opposite negative result as was obvious in heaps A and B. Pereira et al. (1986) informed that $\mathrm{NO}_{3}{ }^{-}$concentrations were less during the initial phases but gradually increased towards the end. On the contrary, $\mathrm{NH}_{4}{ }^{+}$levels were increasing in the initial stages but declined towards the end (Liao et al., 1995). 


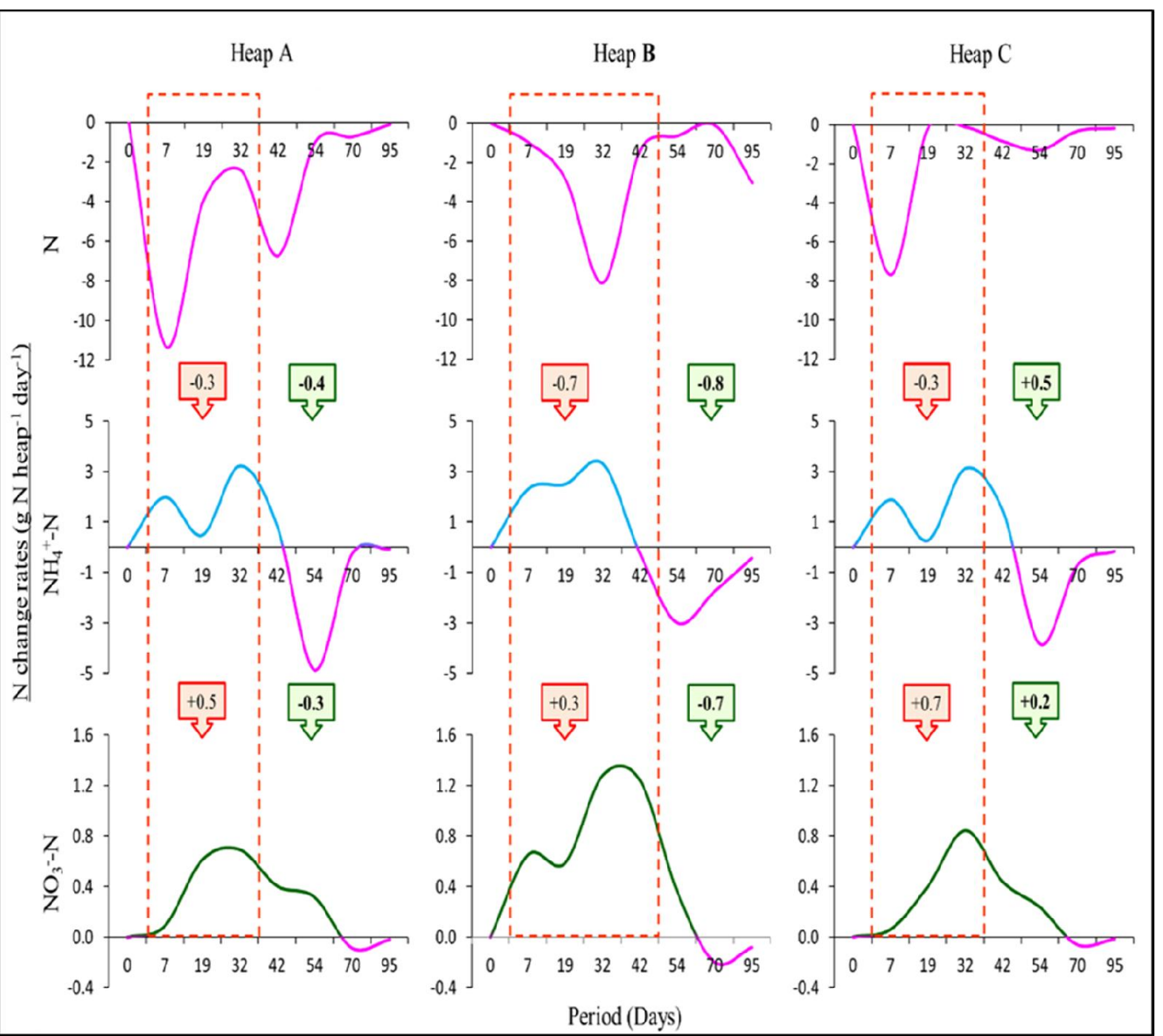

Fig. 10: Rate of change [daily] as loss (-) or gain (+) in nitrogen forms measured in each heap as [g N heap ${ }^{-1}$ day $\left.^{-1}\right]$ including total nitrogen $(\mathrm{N})$, ammonium nitrogen $\left(\mathrm{NH}_{4}{ }^{+}-\mathrm{N}\right)$ and nitrate nitrogen $\left(\mathrm{NO}_{3}{ }^{-}-\mathrm{N}\right)$. Thermophilic stages are bordered by red dot rectangle. The Pearson correlation between change rates of different $\mathrm{N}$ forms are presented in colored squared arrows in accordance with thermal stage.

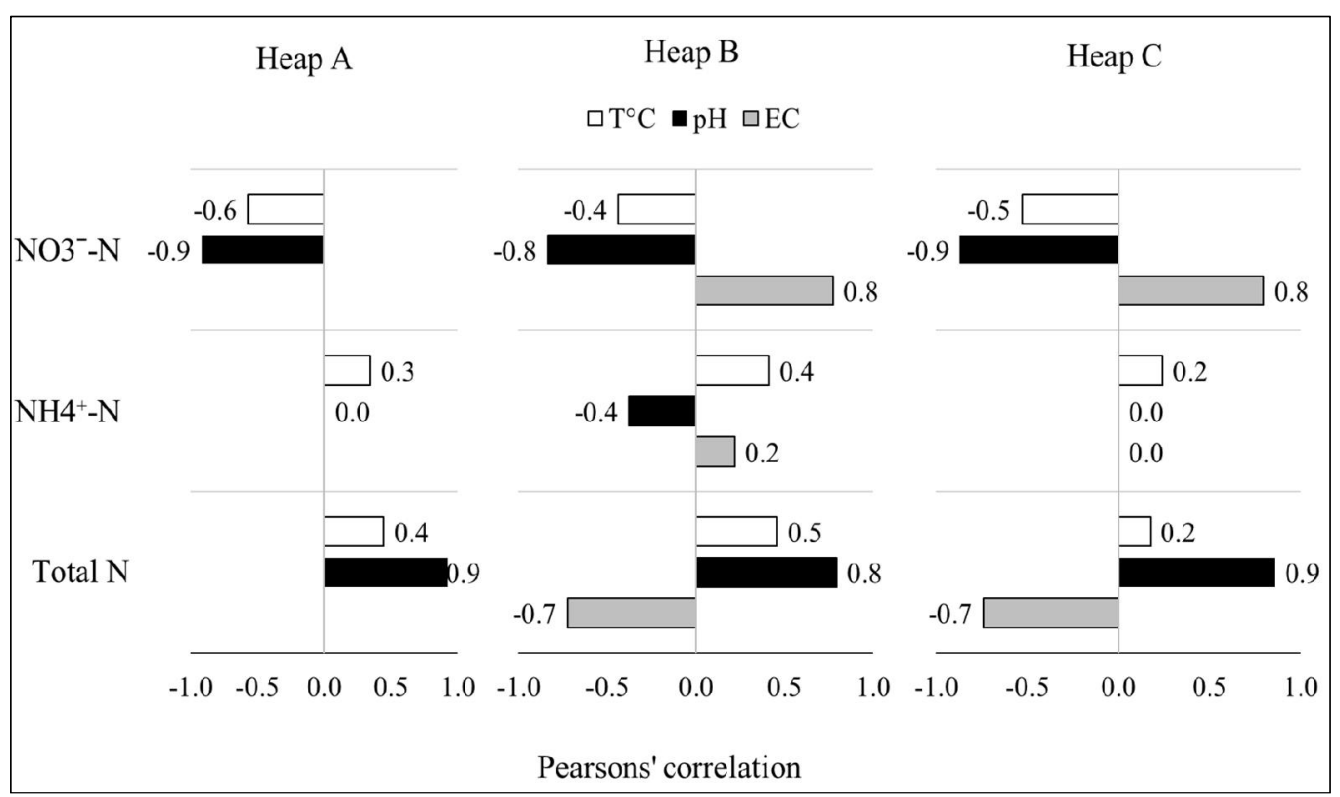

Fig. 11: Correlation of $\mathrm{NH}_{4}{ }^{+}-\mathrm{N}, \mathrm{NO}_{3}{ }^{-}-\mathrm{N}$ and total $\mathrm{N}$ in heaps with their $\mathrm{T}^{\circ} \mathrm{C}, \mathrm{pH}$ and $\mathrm{EC}$ values. 
By comparing losses in $\mathrm{NH}_{4}{ }^{+}-\mathrm{N}$ in the mesophilic stages in the three heaps, it was found that the existence of olive mill waste in heaps $\mathrm{B}$ and $\mathrm{C}$ minimized $\mathrm{NH}_{4}{ }^{+}-\mathrm{N}$ loss than in A by controlling transformations taking place and was much effective in its mixture with fish wastes in heap B as it extended its thermophilic stage for longer period. The lack of olive mill waste in heap A made it more susceptible to lose $\mathrm{NH}_{4}{ }^{+}-\mathrm{N}$ in spite of its high OM decomposition rate.

This was obvious as initial to final $\mathrm{N}$ loss calculated from data in Table (1) was higher in heap A $\left(0.253 \mathrm{~kg} \mathrm{heap}^{-1} \equiv 19.9 \%\right)$ than heap B $\left(0.245 \mathrm{~kg} \mathrm{heap}^{-1} \equiv 17.3 \%\right)$ and lowest in heap C $(0.090 \mathrm{~kg}$ heap $^{-1} \equiv 8.4 \%$ ). In this concept, the existence of olive mill in heaps $\mathrm{B}$ and $\mathrm{C}$ seemed to have a positive role in decreasing $\mathrm{N}$ loss as stated before by Sánchez-Monedero et al. (2010).

The existence of fish wastes in heaps A and B had a positive role in bigger $\mathrm{N}$ loss, as fish wastes are richer in $\mathrm{NH}_{3}$ (Dauda et al., 2019). Nitrogen losses are possible, either by nitrate leaching in the case of unprotected composts piles under rainy season, or by volatilization of ammonia (NH3), and nitrous oxide $(\mathrm{N} 2 \mathrm{O})$.

Bohacz, J. (2019) found that $\mathrm{NH}_{3}$ volatilization was intensified under alkaline conditions of the composted biomass. Based on that, in the present work there was more possibility that more $\mathrm{NH}_{3}$ emissions considered as GHG from all heaps, as their $\mathrm{pH}$ recorded 8-7.5 under their mean temperatures exceeding $45^{\circ} \mathrm{C}$ [thermophilic stages] coinciding with more negative $\mathrm{N}$ change rate [more $\mathrm{N}$ loss] and consequently more positive $\mathrm{NH}_{4}{ }^{+}-\mathrm{N}$ change rate [more $\mathrm{NH}_{4}{ }^{+}-\mathrm{N}$ formed].

Added to that, there was an increase in $\mathrm{NO}_{3}{ }^{-}-\mathrm{N}$ resulting from nitrification of $\mathrm{NH}_{4}{ }^{+}-\mathrm{N}$ and this might had produced other less oxidized forms of nitrogen $\left[\mathrm{N}_{2} \mathrm{O}\right]$ sharing in GHG that had global warming potential 300 times than that caused by $\mathrm{CO}_{2}$ (Park et al., 2017).

According to correlations in Figure (11), temperatures in all heaps were positively correlated to total $\mathrm{N}$ and $\mathrm{NH}_{4}{ }^{+}-\mathrm{N}$, while negatively correlated to $\mathrm{NO}_{3}{ }^{-} \mathrm{N}$ as high temperatures inhibit nitrification process (Grunditz and Dalhammar, 2001). The $\mathrm{pH}$ values were correlated negatively with $\mathrm{NO}_{3}{ }^{-}-\mathrm{N}$ and positively with total $\mathrm{N}$. As $\mathrm{pH}$ decreased by time, less ammonia gas $\mathrm{NH}_{3}$ loss is likely to occur and more $\mathrm{NH}_{4}{ }^{+}-\mathrm{N}$ formed [ obvious from negative correlation in heap B] that was available for nitrification to $\mathrm{NO}_{3}{ }^{-} \mathrm{N}$ form. In fact, $\mathrm{pH}$ favors ammonia by displacing $\mathrm{NH}_{4}^{+} / \mathrm{NH}_{3}$ equilibrium to ammonia or what so called NH3 emission and vice versa (Beck-Friis et al., 2001; Pagnas et al., 2006; Muktadirul et al., 2013). On the contrary, as $\mathrm{pH}$ decreases by time due to formation of more organic acids, $\mathrm{NH}_{3}$ transforms to $\mathrm{NH} 4+$ form (Azim et al., 2017).

\section{Enzymatic activities}

In the three heaps the cellulytic activity was measured as $\mu$ mol glucose $\mathrm{g}^{-1}$ and dehydrogenase activity was measured as $\mu \mathrm{g} \mathrm{TPF} \mathrm{g}^{-1} \mathrm{~h}^{-1}$, while protease activity was measured qualitatively as clear zone test, as shown in Figure (12).

During thermophilic stage, the cellulytic activities behaved nearly the same as dehydrogenase activities in heap $\mathrm{C}$ while they were reversibly correlated in heaps $\mathrm{A}$ and $\mathrm{B}$ recording after 32 days maximum cellulytic activity of 10,10 and $17 \mathrm{FPU} \mathrm{g}^{-1}$, and maximum dehydrogenase activity of 300 , 350 and $200 \mu \mathrm{g} \mathrm{TPF} \mathrm{g}^{-1} \mathrm{~h}^{-1}$, respectively.

The cellulytic activity in heap B was at its maximum recording $1342 \mathrm{FPU} \mathrm{g}^{-1}$ at $70^{\circ} \mathrm{C}$ and 1170 FPU g ${ }^{-1}$ at $60^{\circ} \mathrm{C}$ characterized by its highest correlation of +0.8 among heaps all over the composting periods as shown in Figure (13), while the deHase activity was at its minimum, not favoring temperatures above $60^{\circ} \mathrm{C}$ in heaps B and C. worthy to notice that in Heap A where no olive mill waste shared in it, the deHase activity was maximum at high temperatures to be $224 \mu \mathrm{g} \mathrm{TPF} \mathrm{g}{ }^{-1} \mathrm{~h}^{-1}$ at $60^{\circ} \mathrm{C}$ and $248 \mu \mathrm{g} \mathrm{TPF} \mathrm{g} \mathrm{g}^{-1}$ at $45^{\circ} \mathrm{C}$.

Proteolytic activities appeared in the thermophilic stages and its role ended at the mesophilic stages in the three heaps, which was in agree with the high loss in total $\mathrm{N}$ and the high formation of $\mathrm{NH}_{4}{ }^{+}$in the thermophilic stage in each heap. In this phase, part of the nitrogen from protein became resistant to microbial degradation by its incorporation into humic acids (Roman et al. 2015).

Worthy to mention that cellulytic enzymes degrade cellulosic matter to simpler compounds required to form energy precursors, which was obvious in increased deHase activity as source for ATP which was positively correlated $(+0.5)$ in both heaps $\mathrm{A}$ and $\mathrm{C}$ as shown in Figure (13), while this relation was obvious in heap $\mathrm{B}$ at the end of the thermophilic stage when temperature was $60^{\circ} \mathrm{C}$. 


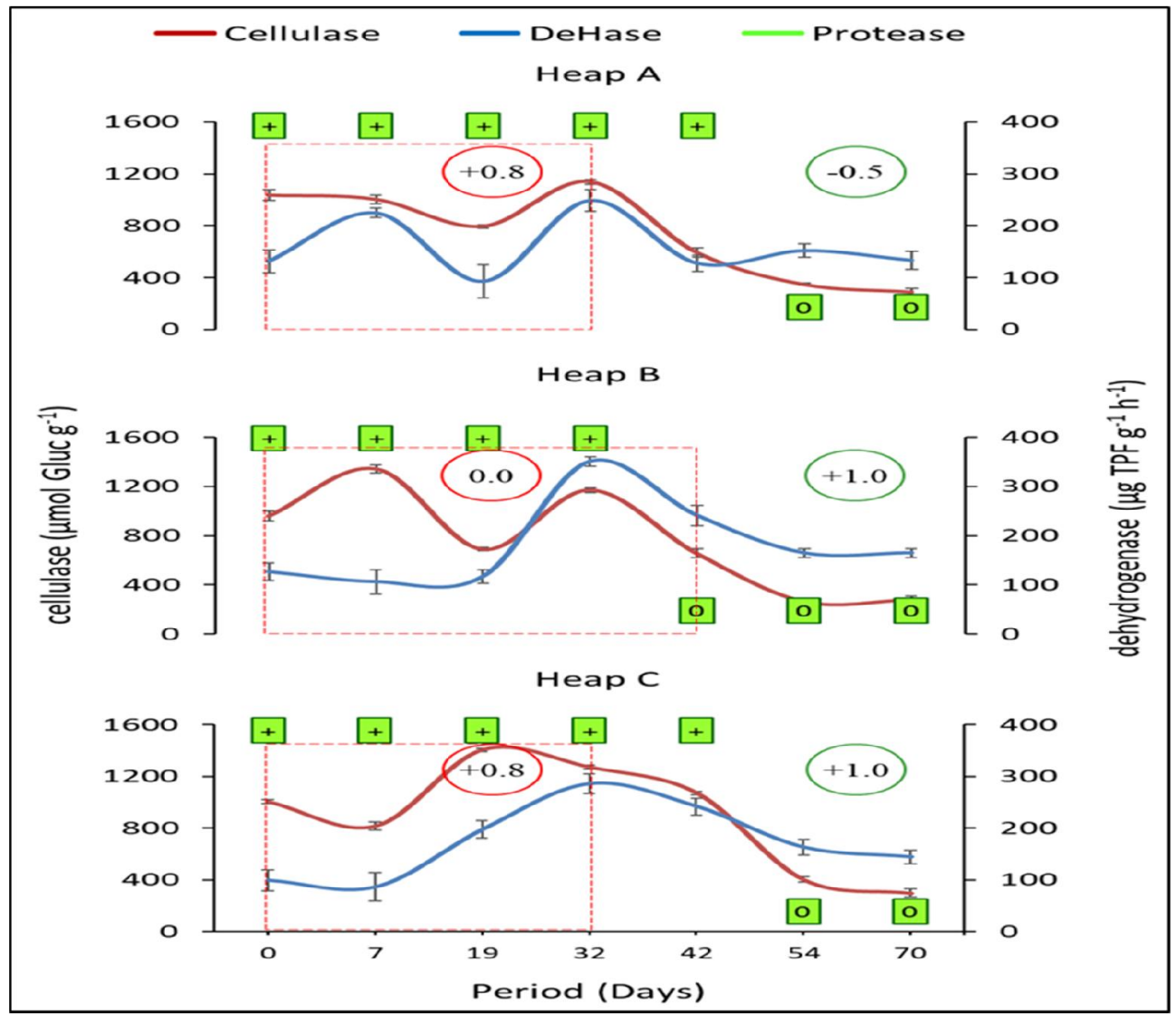

Fig. 12: The cellulase, dehydrogenase (deHase) and protease activities in each of the three heaps during composting period. Correlations between deHase and cellulase in each heap are represented in red and green circles in respect to their thermophilic [red dot rectangle] and mesophilic stages, respectively.

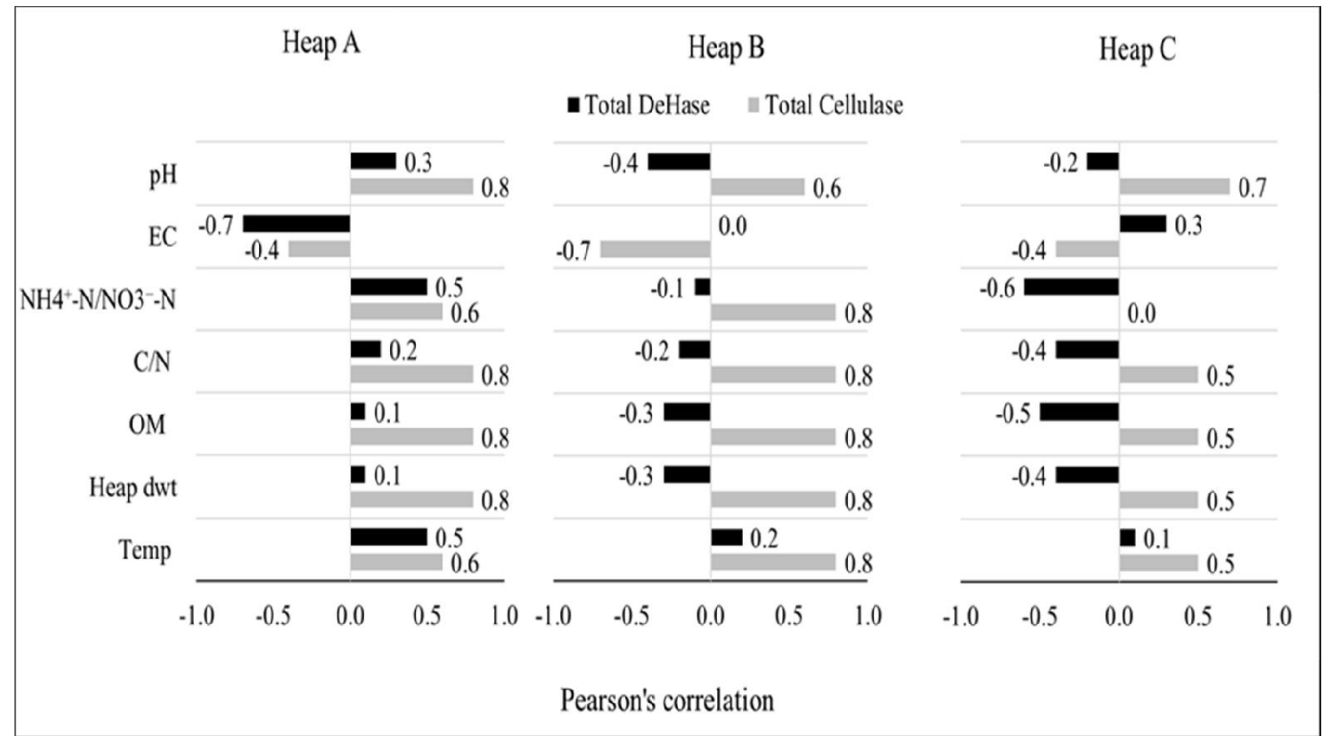

Fig. 13: Correlation of enzymatic activities in heaps with their temperature, dry weight, organic matter, organic matter loss $\%, \mathrm{C} / \mathrm{N}$ ratio, $\mathrm{NH}_{4}{ }^{+}-\mathrm{N} / \mathrm{NO}_{3}{ }^{-}-\mathrm{N}$ ratio, $\mathrm{EC}$ and $\mathrm{pH}$ values. 
The existence of proteolytic activity specifically in the thermophilic stages was followed by its absence in mesophilic stages of the three heaps which was parallel to clear decline in cellulytic deHase activities.

Epstein (1997) found significant positive correlations between temperature and microbial properties such as dehydrogenase activity and microbial biomass. Tiquia (2005) stated that the dehydrogenase activity of the compost was higher at the beginning of composting and decreased as composting proceeded to level-off towards the end of composting. Similarly, Barrena et al. (2008) found that temperature and dehydrogenase activity profiles were similar during thermophilic stage showing rapid increase in the first days of composting.

Maximum dehydrogenase activity recorded was $450 \mu \mathrm{g} \mathrm{TPF} \mathrm{g}^{-1} \mathrm{~h}^{-1}$ at the transient stage between thermophilic and mesophilic stages. At the end of the active thermophilic stage, as maximum values of dehydrogenase activity corresponded to a high biological activity, gradually decreased and extended for long maturation mesophilic period of 60 days. Kazemi et al. (2017) stated that during composting processes, specifically those embedding fish wastes, the activities of oxidoreductase enzyme (as dehydrogenase) and hydrolase enzyme (as $\beta$-glucosidase) decreased with time since available organic compounds decreased.

Mayende et al. (2006) stated that organic matter in composts under study was degraded by cellulolytic and ligninolytic enzymes, as temperatures recorded were above $50{ }^{\circ} \mathrm{C}$. Many isolated thermophilic microorganisms had cellulase and polyphenol oxidase activities, where cellulases optimum temperature was found to be $70{ }^{\circ} \mathrm{C}$. Putting in consideration that a compost pile which is too hot can destroy its own biological community but the lower temperatures apparently allowed for a richer diversity of living things, which in turn have a greater effect on the degradation of the organic matter (Young et al., 2005).

\section{Biological aspects:}

All total coliforms, fecal coliform, Salmonella and Shigella recorded higher load in heap B $>$ A $>$ $\mathrm{C}$ at the beginning of heap formation and remarkably decreased at the beginning but vanished at the end of the thermophilic stage, as shown in Table (3). Parasites existence disappeared at the very beginning of the thermophilic stage.

Table 3: Effect of heaps type and composting process stage on their pathogenic bacteria and parasite contents.

\begin{tabular}{|c|c|c|c|c|c|c|}
\hline $\begin{array}{l}\text { Type of } \\
\text { heap }\end{array}$ & $\begin{array}{c}\text { Heap } \\
\text { temperature }\end{array}$ & $\begin{array}{l}\text { period } \\
\text { (days) }\end{array}$ & $\begin{array}{c}\text { Total coliform } \\
\times 10^{4}\end{array}$ & $\begin{array}{c}\text { Fecal coliform } \\
\times 10^{4}\end{array}$ & $\begin{array}{c}\text { Salmonella }+ \text { Shigella } \\
\times 10^{3}\end{array}$ & $\begin{array}{c}\text { Parasite } \\
\text { type }\end{array}$ \\
\hline \multirow{4}{*}{$\mathbf{A}$} & 25 & 0 & 310 & 300 & 250 & $\mathrm{AW}, \mathrm{BC}, \mathrm{EH}$ \\
\hline & 60 & 7 & 187 & 110 & 13 & $\mathrm{AW}, \mathrm{EC}, \mathrm{G}$ \\
\hline & 45 & 19 & 110 & 90 & 5 & - \\
\hline & 45 & 32 & 0 & 0 & 0 & - \\
\hline \multirow{4}{*}{ B } & 25 & 0 & 350 & 310 & 290 & $\mathrm{EC}, \mathrm{EH}$ \\
\hline & 70 & 7 & 210 & 112 & 18 & $\mathrm{AW}, \mathrm{BC}, \mathrm{G}$ \\
\hline & 50 & 19 & 110 & 29 & 4 & - \\
\hline & 60 & 32 & 0 & 0 & 0 & - \\
\hline \multirow{4}{*}{$\mathbf{C}$} & 25 & 0 & 301 & 280 & 210 & EC \\
\hline & 60 & 7 & 104 & 42 & 11 & - \\
\hline & 40 & 19 & 7 & 2 & 2 & - \\
\hline & 45 & 32 & 0 & 0 & 0 & - \\
\hline
\end{tabular}

(AW) Ascaris worms, (BC) Balantidium coli, (G) Gridialambila, (EC) Entamoeba coli, (EH) Entamoeba histolitica.

As total coliforms, fecal coliform, Salmonella and Shigella recorded higher load in heap B $>A>C$ at the beginning of heap construction apparently correlated to their rich content in fish waste than cattle dung and remarkably decreased by the beginning of the thermophilic stage until they vanished before its end. Parasites existence and types were also bound to the fish waste content that disappeared the very beginning of the thermophilic stage. Worthy to mention, thermophilic stage extending more than 25 days ensured sanitation of the heaps.

Young et al. (2005) stated that the antagonism and competition on nutrients between compost microorganisms, beside the heat generating from their metabolic activities during composting 
destroyed all of pathogens. Added to that, temperature of $50^{\circ} \mathrm{C}$ for $24 \mathrm{~h}$ was sufficient to kill all the pathogens while lower temperature of $46^{\circ} \mathrm{C}$ will take longer time of nearly a week to kill those pathogens. Barrena et al. (2008) stated that during composting the thermophilic stage extended for 20 days recording temperature of $70^{\circ} \mathrm{C}$ at the beginning then $>45^{\circ} \mathrm{C}$ which ensured complete sanitation of the material.

\section{Comparative evaluation of compost analytical parameters:}

As shown in Table (4), most heavy metal concentrations didn't exceed or even approach those maximum limits defined by worldwide countries standards, except for $\mathrm{Cd}$ that exceeded maximum limits for three European countries only (Hogg et al., 2002). Worthy to notice that Cd concentration apparently bound to cattle dung sharing in composts more than fish waste.

In Table (5), several chemical and biological analyses were shown facilitating evaluation of compost maturation and expected efficiency. Compost $(\mathrm{B})$ had the lowest $\mathrm{C}$ : $\mathrm{N}$ ratio among others to be 11.1 which was considered the best as it was closer to ideal [10:1] than the others. As stated by Young et al. (2005), C:N ratio after composting was important in determining the value of finished compost as soil amendment for crops, by which the final $\mathrm{C}: \mathrm{N}$ ratio of 10 would be ideal and above 20 had negative impact that would damage both seed germination and crop. $\mathrm{NH}_{4}{ }^{+}-\mathrm{N}^{-} \mathrm{NO}_{3}{ }^{-}-\mathrm{N}$ ratio recorded in compost $(\mathrm{B})$ and $(\mathrm{A})$ was 0.34 , to be lower than in $(\mathrm{C})$ which was 0.52 . The lower the ratio the more stable $\mathrm{N}$ form as nitrate than ammonia.

The $\mathrm{P}$ and $\mathrm{K}$ concentrations in the composts were much higher in heaps (B) and (A) than (C) being $(\mathrm{P} / 1.4, \mathrm{~K} / 0.95),(\mathrm{P} / 1.9, \mathrm{~K} / 1.5)$ and $(\mathrm{P} / 0.85, \mathrm{~K} / 0.79) \mathrm{ppm}$, respectively, as $\mathrm{P}$ was much correlated to fish wastes used in composts $(\mathrm{A})$ and $(\mathrm{B})$, while $\mathrm{K}$ was more correlated to both fish wastes and olive mill as shown in Figure (11). Similarly, Kusuma et al., (2019) confirmed through their work that composting fish wastes resulted in compost richer in $\mathrm{P}$ and $\mathrm{K}$ than composting agricultural and municipal solid wastes, fulfilling the compost quality according to Indonesian National Standards (SNI). Worthy to mention that wastes from fish processing were found to be rich in phosphorus as well as organic materials with high levels of nitrogen and by composting provide nutrient rich natural fertilizers (Radziemska et al., 2019; Sepp et al., 2019).

Table 4: Heavy metal contents in the three final composts compared to some global standards (mg. $\mathrm{Kg}^{-1}$ as dry weight).

\begin{tabular}{|c|c|c|c|c|c|c|}
\hline \multirow[t]{2}{*}{ Compost } & Cd & $\mathrm{Cr}$ & $\mathrm{Cu}$ & $\mathbf{N i}$ & $\mathbf{P b}$ & Zn \\
\hline & \multicolumn{6}{|c|}{$\left(\mathrm{mg} . \mathrm{Kg}^{-1}\right)$} \\
\hline $\mathbf{A}$ & 2.6 & 20.9 & 22.5 & 12.3 & 16.9 & 207.7 \\
\hline B & 1.2 & 18.2 & 40.3 & 13.7 & 15.1 & 147.1 \\
\hline C & 1.7 & 13.5 & 254 & 11.6 & 7.3 & 66.5 \\
\hline USA NY & 10 & 100 & 1000 & 200 & 250 & 2500 \\
\hline USA WA & 10 & 600 & 750 & 210 & 150 & 1400 \\
\hline USA Texas & 16 & 180 & 1020 & 160 & 300 & 2190 \\
\hline Canada & 3 & 210 & 100 & 62 & 150 & 500 \\
\hline Australia & 3 & 400 & 200 & 60 & 200 & 250 \\
\hline New Zealand & 15 & 1000 & 1000 & 200 & 600 & 2000 \\
\hline UK & 1.5 & 100 & 200 & 50 & 150 & 400 \\
\hline France & 3 & - & - & 200 & 800 & - \\
\hline Germany & 1.5 & 100 & 100 & 50 & 150 & 400 \\
\hline Spain & 2 & 250 & 300 & 100 & 150 & 400 \\
\hline
\end{tabular}

Elements [Cd: cadmium, Cr: chromium; Cu: cupper; Ni: nickel; Pb: lead; Zn: zinc]

NY: New York; WA: Washington; UK: United Kingdom 


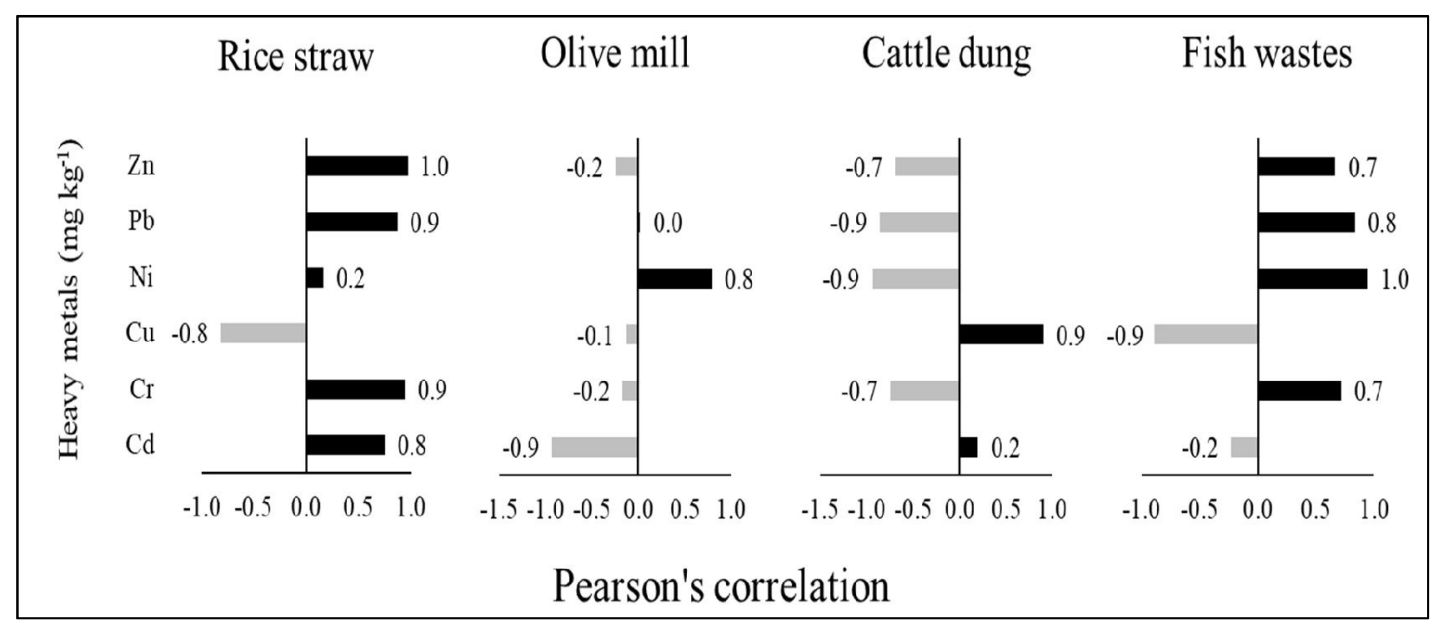

Fig. 14: Wastes type and quantity used correlated to final heavy metal analysis in all composts. Gray and black cells refer to negative and positive correlations, respectively.

Salinity was apparently correlated to the presence of olive mill $(+0.5)$ and cattle dung $(+0.4)$ in the composts (C) and (B), as it could be predicted from Pearson's correlations illustrated in Figure (15) recording 3.70 and $3.50 \mathrm{dsm}$ as shown in Table (7), respectively, putting in consideration that fish wastes used from local markets were from fresh water resource and not marine. On the contrary, CEC was higher in composts (A) and (B) as both were constructed from fish wastes recording 5.33 and $5.18 \mathrm{eq} / 100 \mathrm{~g}$, respectively, that were much correlated to the use of both fish wastes $(+0.9)$ and rice straw $(+0.8)$.

Phytotoxic chemicals produced during composting might significantly impact on germination and plant growth, as in many instances composting can also be a source of xenobiotic and hazardous volatile organic compounds (Cheng and Cheng 2015). In the present study, GI for extracts from compost (B) was higher than from (A) than (C), recording $84.9 \%, 79.30 \%$ and $74.10 \%$, respectively, which was much positively correlated to fish waste $(+1.0)$ and negatively correlated to cattle dung (-1.0). In this concept, López-Mosquera et al. (2011) found that the germination index in compost embedding fish wastes reached above $80 \%$ indicating the absence of phytotoxic substances or their presence in very low levels.

HI for heap B recorded 0.19 to be the lowest proving that humified portion of organic matter was much bigger than the non-humified substances especially that it had the best HD\% compared to the other two composts. Worthy to notice the HI results were negatively correlated to both fish waste ($0.9)$ and olive mill $(-0.8)$ as shown in Figure (15) as when they were used together as in compost B gave lowest $\mathrm{HI}$ to be (0.19) than if used separately in composts A (0.39) and C (0.48) as shown on Table (5). Humic substances are considered as indicators for good biodegradation and biotransformation of protein, cellulose, and hemicelluloses during the process (Chefetz et al., 1998).

As can be seen in Figure (15), the fish waste was good source for P and $\mathrm{K}$ followed by olive mill. Decrease in $\mathrm{pH}$ value was correlated more too olive mill and vice versa with rice straw. While olive mill and cattle dung were correlated to increase in EC, the rice straw and fish waste were correlated to its decrease. On the other hand, CEC increased when rice straw and fish waste were used and severely decreased with cattle dung. GI was much better with fish wastes followed by olive mill while was much negatively affected by cattle dung quantity. More $\mathrm{N}$ content in the final form of composts was correlated to fish wastes and olive mill, while $\mathrm{NH}_{4}{ }^{+}-\mathrm{N} / \mathrm{NO}_{3}{ }^{-} \mathrm{-}$ ratio equilibrium displaced to nitrate was much correlated to the use of fish waste and rice straw and reversibly to cattle dung. Among carbon sources, olive mill strongly correlated to $\mathrm{N} \%$ and $\mathrm{OM} \%$ same as fish waste.

Generally, highest values in $\mathrm{CEC}, \mathrm{GI} \%, \mathrm{NO}_{3}$, beside $\mathrm{P}, \mathrm{K}$ and $\mathrm{Zn}$ contents, while lower $\mathrm{C}: \mathrm{N}$ ratio, $\mathrm{EC}$ and $\mathrm{HI}$ were characterizing heap $\mathrm{B}$ than $\mathrm{A}$ and $\mathrm{C}$, where fish wastes and olive mill were used together. Similarly recommended by Muktadirul et al. (2013), they advised that to reach an ideal C/N ratio in final mature compost (10 to15), with suitable organic matter content and high total nitrogen concentration, it is recommended to use olive mill wastes with fish wastes. In addition, compost B contained acceptable quantities of heavy metals as Ni needed by plant for growth and functioning 
beside its role with $\mathrm{Cu}$ as beneficial ions regulating plant's reactive oxygen species (ROS) scavenging system, as stated by Izosimova, (2005).

Table 5: Comparative initial and final chemical and biological analysis for each compost

\begin{tabular}{|c|c|c|c|c|}
\hline Analyte & Period & $\mathbf{A}$ & B & $\mathrm{C}$ \\
\hline \multirow{2}{*}{ ОМ\% } & I & 72.38 & 83.28 & 62.34 \\
\hline & II & 33.09 & 39.41 & 37.93 \\
\hline \multirow{2}{*}{ N\% } & I & 1.30 & 1.50 & 1.26 \\
\hline & II & 1.63 & 2.06 & 1.48 \\
\hline \multirow{2}{*}{$C: N$} & I & 32.29 & 32.20 & 28.60 \\
\hline & II & 11.77 & 11.10 & 14.76 \\
\hline \multirow{2}{*}{$\mathrm{NH}_{4}{ }^{+}-\mathrm{N} / \mathrm{NO3}^{-}-\mathrm{N}$} & I & 24.29 & 3.80 & 32.60 \\
\hline & II & 0.34 & 0.34 & 0.52 \\
\hline \multirow{2}{*}{ GI } & I & 5.30 & 7.50 & 10.30 \\
\hline & Il & 79.30 & 84.90 & 74.10 \\
\hline \multirow{2}{*}{ НА\% } & I & 5.90 & 5.30 & 4.50 \\
\hline & II & 11.30 & 10.50 & 11.50 \\
\hline \multirow{2}{*}{ FA\% } & I & 7.50 & 6.20 & 6.40 \\
\hline & Il & 7.10 & 5.60 & 6.20 \\
\hline \multirow{2}{*}{ HI ratio } & I & 1.67 & 0.62 & 2.30 \\
\hline & II & 0.39 & 0.19 & 0.48 \\
\hline \multirow{2}{*}{ HR \% } & I & 34.56 & 24.66 & 31.81 \\
\hline & II & 95.80 & 70.40 & 83.88 \\
\hline \multirow{2}{*}{ HD \% } & I & 37.87 & 38.43 & 29.86 \\
\hline & Il & 71.70 & 83.80 & 77.30 \\
\hline \multirow{2}{*}{ CEC (eq/100g) } & I & 3.10 & 2.80 & 1.90 \\
\hline & II & 5.33 & 5.18 & 3.79 \\
\hline \multirow{2}{*}{ EC (dsm) } & I & 1.70 & 1.50 & 2.30 \\
\hline & II & 3.00 & 3.50 & 3.70 \\
\hline \multirow{2}{*}{ pH } & I & 8.73 & 8.15 & 8.94 \\
\hline & Il & 7.09 & 6.96 & 7.00 \\
\hline \multirow{2}{*}{ P \% } & I & 0.50 & 0.80 & 0.30 \\
\hline & Il & 1.40 & 1.90 & 0.85 \\
\hline \multirow{2}{*}{ K \% } & I & 0.60 & 0.90 & 0.85 \\
\hline & II & 0.95 & 1.50 & 0.79 \\
\hline \multirow{2}{*}{ P.O / $/ 100 \mathrm{~g}$} & I & G.E.A & G.E.A & $\mathrm{E}$ \\
\hline & Il & N.d & N.d & N.d \\
\hline \multirow{2}{*}{ N.L/200g } & I & N.d & N.d & N.d \\
\hline & II & N.d & N.d & N.d \\
\hline \multirow{2}{*}{ T.C (x10) } & I & 187 & 210 & 210 \\
\hline & II & N.d & N.d & N.d \\
\hline \multirow{2}{*}{ F.C $\left(\mathrm{x}^{10^{4}}\right)$} & I & 110 & 112 & 112 \\
\hline & II & N.d & N.d & N.d \\
\hline \multirow{2}{*}{ S.S $\left(\mathrm{x10}^{3}\right)$} & I & 13 & 18 & 18 \\
\hline & II & N.d & N.d & N.d \\
\hline
\end{tabular}

I: initial after one week, II: Final compost, CEC: Cation exchange capacity, HA: Humic acid, FA: Fulvic acid, HI: humification index, HR: humification rate, HD: humification degree, N.d: not detected, GI: Germination index, $\boldsymbol{G}$.: Gardai lambila, E.: Entamoeba coli, A.: Ascaris worms, B.: Balantidum coli, S.S: Salmonella and Shigella, T.C: Total coliform, F.C: Fecal coliform, P.O: Parasites Ova, N.L: Nematode Larva. 


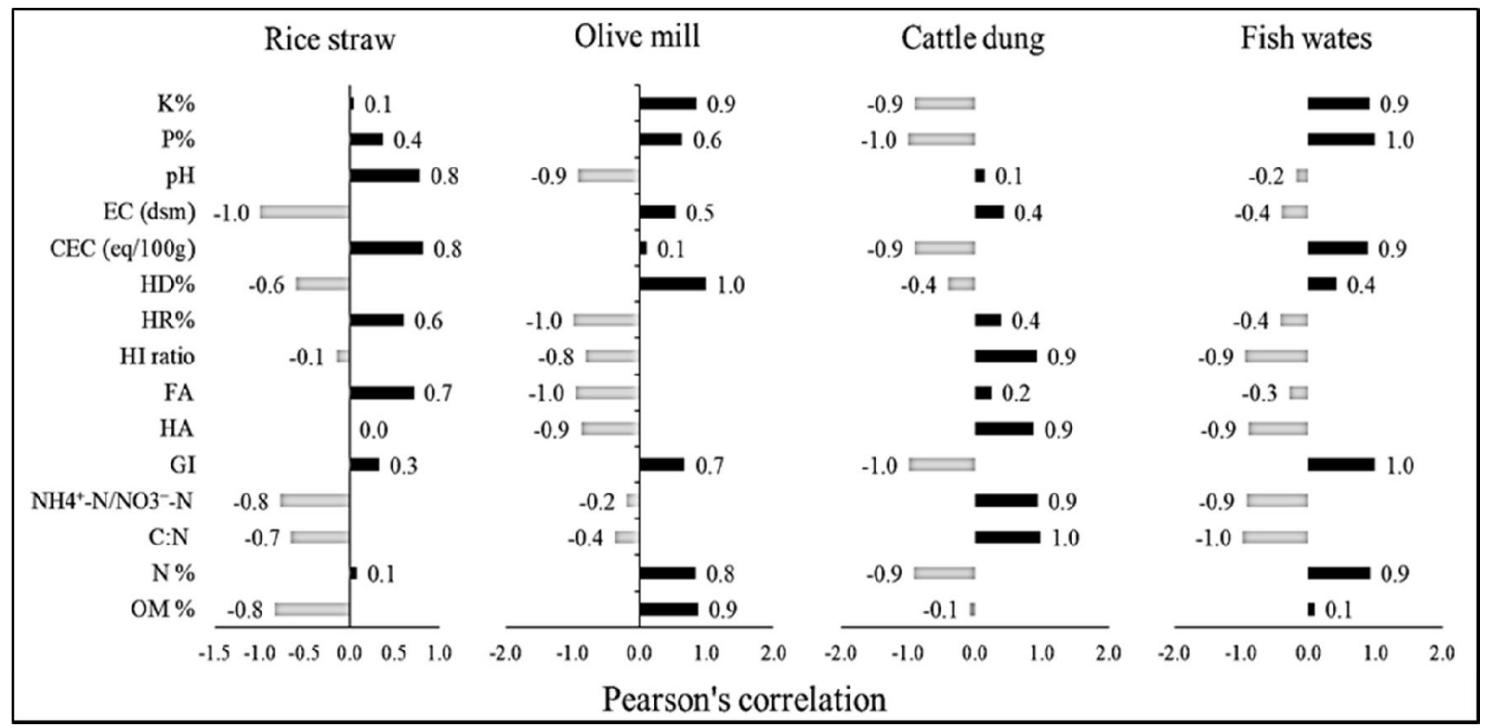

Fig. 15: Wastes type and quantity used correlated to final analysis in all composts. Gray and black cells refer to negative and positive correlations, respectively.

\section{Conclusion}

Gathering olive mill and rice straw in equal quantities with fish waste being the sole $\mathrm{N}$ source in heap B made it the best choice for composting formulation than the other two heaps, as the final compost was higher in $\mathrm{N} \%$ and $\mathrm{OM} \%$. Also compost $\mathrm{B}$ contained more $\mathrm{K}$ and $\mathrm{P}$ beside high $\mathrm{Zn}$ content which proved to be essential for metabolic processes in plants.

\section{References}

Afifi, M.M.I., 2010. Biochemical Studies on Humic Substances Extracted from Organic Fertilizers. Ph.D. Thesis, Dep. of Microbiology, Fac. Agric. Cairo University, 156.

APHA (American Public Health Association), 1989. Municipal Refuse Disposal. $3^{\text {rd }}$ ed. Public Administration Service, Chicago, USA.

Azim, K., B. Soudi, S. Boukhari, C. Perissol, S. Roussos, and A.I. Thami 2017. Composting parameters and compost quality: a literature review. Organic Agriculture, doi: 10.1007/s13165-017-0180-z

Baetahall, L., C.M. Sàagua, M.L. Bartolomeu, A.M. Anselmo, and M.F. Rosa, 2005. Biodegradation of olive oil husks in composting aerated piles. Bioresource Technology, 96:69-78, doi: 10.1016/j.biortech.2003.06.007

Barrena R., F. Vazquez and A. Sanchez, 2008. Dehydrogenase activity as a method for monitoring the composting process. Bioresource Technology, 99:905-908, doi: 10.1016/j.biortech.2007.01.027

Beck-Friis, B., S. Smars, H. Jonsson, and H. Kirchmann, 2001. Gaseous emissions of carbon dioxide, ammonia and nitrous oxide from organic household waste in a compost reactor under different temperature regimes. Journal of Agricultural Engineering Research, 78:423-430. doi: 10.1006/jaer.2000.0662

Bernal, M.P., J.A. Alburquerque, and R. Moral, 2009. Composting of animal manures and chemical criteria for compost maturity assessment. A review. Bioresource Technology 100:5444-5453, doi: 10.1016/j.biortech.2008.11.027

Bishop, P.L. and C. Godfrey, 1983. Nitrogen transformations during sludge composting. BioCycle, 24:34-39.

Bohacz, J., 2019. Changes in mineral forms of nitrogen and sulfur and enzymatic activities during composting of lignocellulosic waste and chicken feathers. Environmental Science and Pollution Research, 26(10):10333-10342.

doi: $10.1007 / \mathrm{s} 11356-019-04453-2$ 
Cairo airport weather forecast (HECA), Available at:

https://www.wunderground.com/history/monthly/eg/cairo/HECA/date/2011-0

Casida, L., D. Klein, and T. Santoro, 1964. Soil dehydrogenase activity. Soil Science, 98:371-376. doi: 10.1097/00010694-196412000-00004

Chapman, H.D. and P.F. Pratt, 1962. Methods of analysis for soils, plants and water. Soil Science, 93(1):68. doi: 10.1097/00010694-196201000-00015

Chefetz, B., F. Adani, P. Genevini, F. Tambone, Y. Hadar, and Y. Chen., 1998. Humic acid transformation during composting of municipal solid waste. Journal of Environmental Quality, 27:794-800, doi: 10.2134/jeq1998.00472425002700040011x

Cheng, F. and Z. Cheng, 2015. Research progress on the use of plant allelopathy in agriculture and the physiological and ecological mechanisms of allelopathy. Frontiers in Plant Science, 6(1020). doi: 10.3389/fpls.2015.01020

Ciavatta, C., M. Govi, L.V. Antisati, and P. Sequi, 1990. Characterization of humified compounds by extraction and fractionation on solid polyphenylpyrrolidone. Journal of Chromatography A, 509(1):141-146. doi: 10.1016/s0021-9673(01)93248-0.

Cooperband, L., 2002. The art and science of composting: A resource for farmers and compost producers. Center of Integrated Agricultural Systems, University of Wisconsin-Madison, USA. Available at: http://www.cias.wisc.edu/wp-content/uploads/2008/07/artofcompost.pdf

Cowan, D.A. and R.M. Daniel, 1982. A modification for increasing the sensitivity of the casein-agar plate assay: a simple semiquantitative assay for thermophilic and mesophilic proteases. Journal of Biochemical and Biophysical Methods, 6(1):31-37. doi: 10.1016/0165-022x(82)90023-9

Cuniff, P.A., 1995. Official Methods of Analysis of AOAC International, 16th edition. Method: 2.7.08, Chapter 2, p. 37.

Das, K. and H.M. Keener, 1997. Moisture effect on compaction and permeability in composts. Journal of Environmental Engineering. 123(3):275-281, doi: 10.1061/(asce)0733-9372(1997)123:3(275)

Dauda, A.B., A. Ajadi, A.S. Tola-Fabunmi, and A.O. Akinwole, 2019. Waste production in aquaculture: Sources, components and managements in different culture systems. Aquaculture and Fisheries, 4(3):81-88. doi: 10.1016/j.aaf.2018.10.002

Difco manual, $11^{\text {th }}$ ed. 1998. Difco Laboratories, Division of Becton Dickinson and Company. Sparks, Maryland 21152, USA.

Duchaufour, P. and F. Jacquin, 1966. Nouvelles recherches sur l'extraction et le fractionnement des composés humiques. Bulletin de 1' École Superieure Agronomiques de Nancy, 8(1):3-24.

Epstein, E., 1997. The Science of Composting. Boca Raton: CRC Press,

Finstein, M.S., F.C. Miller, and P.F. Strom, 1986. Waste treatment composting as a controlled system. pp. 363-398. In: W. Schenborn (ed). Biotechnology. Vol. 8-Microbial degradations. VCH Verlaqsgedellschaft (German Chemical Society): Weinheim F.R.G.

Gajalakshmi, S. and S.A. Abbasi, 2008. Solid waste management by composting: state of the art. Critical Reviews on Environmental Science and Technology. 38:311-400. doi: 10.1080/10643380701413633

Ghose, T.K., 1987. Measurement of Cellulase Activities.Pure and Applied Chemistry, 59: 257-268.

Gigliotti, G., P. Proietti, D. Said-Pullicino, L. Nasini, D. Pezzolla, L. Rosati, and P.R. Porceddu, 2012. Co-composting of olive husks with high moisture contents: organic matter dynamics and compost quality. International Biodeterioration and Biodegradation. 67:8-14, doi: 10.1016/j.ibiod.2011.11.009

Grunditz, C. and G. Dalhammar, 2001. Development of nitrification inhibition assays using pure cultures of Nitrosomonas and Nitrobacter. Water Research, 35:433-440. doi: 10.1016/s0043-1354(00)00312-2

Hamoda, M. F., H.A. Abu Qdais, and J. Newham, 1998. Evaluation of municipal solid waste composting kinetics. Resources, Conservation and Recycling, 23:209-223, doi: 10.1016/s0921-3449(98)00021-4. 
Hogg, D., J. Barth, E. Favoino, M. Centemero, V. Caimi, F. Amlinger, W. Devliegher, W. Brinton, and S. Antler, 2002. Comparison of compost standards within the EU, North America and Australasia, main report. Published by: The Waste and Resources Action Programme (WRAP), Oxon. Available at: http://www.wrap.org.uk/ applications/publications/ publication details. rm?id=698\&publication $=326 \&$ prog ramme $=$ wrap

Hseu, Z.Y., 2004. Evaluating heavy metal contents in nine composts using four digestion methods. Bioresource Technology, 95:53-59. doi: 10.1016/j.biortech.2004.02.008

Izosimova, A., 2005. Modelling the Interaction between Calcium and Nickel in the Soil-Plant System. The Federal Agricultural Research Center (FAL) (German: Bundesforschungsanstalt für Landwirtschaft), Special issue 288:99.

Jackson, M.L., 1973. Soil Chemical Analysis. Prentice Hall of Englewood Cliffs, New Jersy, pp: 925.

Kazemi, K., B. Zhang, L.M. Lye, and Z. Zhu, 2017. Evaluation of state and evolution of marine fish waste composting by enzyme activities. Canadian Journal of Civil Engineering, 44:348-357, Doi: 10.1139/cjce-2016-0377.

Kazemi, K., B. Zhang, L.M. Lye, Q. Cai and T. Cao, 2016. Design of experiment (DOE) based screening of factors affecting municipal solid waste (MSW) composting. Waste Management, 58:107-117, doi: 10.1016/j.wasman.2016.08.029

Kusuma, M.I., Syafrudin and B. Yulianto, 2019. Utilization of fish waste processing as compost raw material in Tambak Lorok market. E3S Web of Conferences, 125, 07004. doi: 10.1051/e3sconf/201912507004

Lenore, S.C., E.G. Arnold, and D.E. Andrew, 1998 Standard methods for the examination of water and wastewater. American Public Health Association (APHA). American Water Works Association (AWWA) and World Environment Federation (WEF). $20^{\text {th }}$ Edition, Washington DC.

Liao, P.H., A.C. May, and S.T. Chieng, 1995. Monitoring process efficiency of full-scale invessel system for composting fisheries wastes. Bioresource Technology, 54:159-163. doi: 10.1016/0960-8524(95)00123-9

López-Mosquera, M.E., E. Fernández-Lema, R. Villares, R. Corral, B. Alonso, and C. Blanco, 2011. Composting fish waste and seaweed to produce a fertilizer for use in organic agriculture. Procedia Environmental Sciences, 9:113-117. doi: 10.1016/j.proenv.2011.11.018

Mayende, L., B.S. Willhelmi, and B.I. Pletschke, 2006. Cellulases (CMCases) and polyphenol oxidases from thermophilic Bacillus spp. Isolated from compost. Soil Biology and Biochemistry, 38(9):2963-2966. doi: 10.1016/j.soilbio.2006.03.019

Miller, G.L., 1959. Use of dinitrosalicylic acid reagent for determination of reducing sugar. Analytical Chemistry, 31:426-428. doi: 10.1021/ac60147a030

Muktadirul Bari Chowdhury, A.K.M., C.S. Akratos, D.V. Vayenas, and S. Pavlou, 2013. Olive mill waste composting: A review. International Biodeterioration and Biodegradation, 85:108-119. doi: 10.1016/j.ibiod.2013.06.019

Murphey, J. and J.P. Riley, 1962. A modified single solution method for the determination of phosphate in natural water. Analytical Chemistry Acta, 27:31-36. doi: 10.1016/S0003-2670(00)88444-5

Mustin, M., 1987. Editor: Dubusc, F. (Ed.), Le compost. Gestion de la Matiere Organique, Paris, pp. 117-263, ISBN 2-864-72008-6

Naylor, L.M., 1996. Composting. Environmental and Science and Pollution series. 18(69):193-269.

Pace, M.G., B.E. Miller, and K.L. Farrell-Poe, 1995. "The Composting Process". Utah State University, AG-WM, volume 1. All Archived Publications. Paper 48. Available at: https://digitalcommons.usu.edu/extension_histall/48

Pagan,s E., R. Barrena, X. Font, and A. Sanchez, 2006. Ammonia emissions from the composting of different organic wastes. Dependency on process temperature. Chemosphere, 62:1534--1542, doi: 10.1016/j.chemosphere.2005.06.044 
Paredes, C., J. Cegarra, A. Roig, M.A. Sanchez-Monedero, and M.P. Bernal, 1999. Characterization of olive mill wastewater (alpechin) and its sludge for agricultural purposes. Bioresource Technology. 67:111-115. doi: 10.1016/S0960-8524(98)00106-0

Park, D., H. Kim, and S. Yoon, 2017. Nitrous oxide reduction by an obligate aerobic bacterium, Gemmatimonas aurantiaca strain T-27. Applied and Environmental Microbiology. 83(12): e00502-17. doi: 10.1128/AEM.00502-17.

Pereira Neto, J.T., E.I. Stentiford, and D.D. Mara, 1986 Comparative survival of pathogenic indicators in windrow and static pile. In Compost: Production, Quality and Use. Ed. De Bertoldi, M., Ferranti, M.P., l'Hermite, P. and Zucconi, F. Elsevier Applied Science, London and New York, 276-295.

Qiao, C., C. Ryan Penton, C. Liu, Z. Shen, Y. Ou, Z. Liu, X. Xu, R. Li, and Q. Shen, 2019. Key extracellular enzymes triggered high-efficiency composting associated with bacterial community succession. Bioresource Technology, 288:121576. doi: 10.1016/j.biortech.2019.121576.

Radziemska, M., M.D. Vaverková, D. Adamcová, M. Brtnický, and Z. Mazur, 2019. Valorization of fish waste compost as a fertilizer for agricultural use. Waste Biomass Valorization, 10(9):2537-2545. doi: 10.1007/s12649-018-0288-8.

Roman, P., M.M. Martinez, and A. Pantoja, 2015. Farmer's Compost Handbook: Experiences in Latin America. FAO Rome. ISBN: 978-92-5-107845-7. Available at: http://www.fao.org/3/ai3388e.pdf

Rosner, B.A., 2006. Fundamentals of biostatistics. Belmont: Duxbury Press. $6^{\text {th }}$ ed. pp. 868 . ISBN $0534418201,9780534418205$.

Said-Pullicino, D. and G. Gigliotti, 2007. Oxidative biodegradation of dissolved organic matter during composting. Chemosphere, 68(6):1030-1040, doi: 10.1016/j.chemosphere.2007.02.012

Sánchez-Monedero, M.A., N. Serramiá, C.G. Civantos, A. Fernández-Hernández, and A. Roig, , 2010. Greenhouse gas emissions during composting of two-phase olive mill wastes with different agroindustrial by-products. Chemosphere, 81(1):18-25. doi: 10.1016/j.chemosphere.2010.07.022.

Saviozzi, A., R. Cardelli, and M. Cozzolino, 2009. Bioremediation with compost of a diesel contaminated soil: monitoring by dehydrogenase activity and basal respiration. Compost Science and Utilization, 17(1):55-60. doi: 10.1080/1065657X.2009.10702400

Schollenberger, C.J. and R.H. Simon, 1945. Determination of exchange capacity and exchangeable bases in soils-ammonium acetate method. Soil Science, 59(1):13-24.

Sepp, M., A. Kisand, M. Shanskiy, M. Silm, and M. Kriipsalu, 2019. Comparison of nutrient bioavailability in fish compost and in alternative composts. Geophysical Research Abstracts, 21: EGU2019-14262.

Smith, H. V., 1999. Detection of parasites in the environment. Parasitology, 117(7):113-141. doi: 10.1017/s0031182099004898

Tiquia, S.M., 2005. Microbiological parameters as indicators of compost maturity. Journal of Applied Microbiology, 99:816-828. doi: 10.1111/j.1365-2672.2005.02673.x

Tortosa, G., J.A. Alburquerque, G. Ait-Baddi, and J. Cegarra, 2012. The production of commercial organic amendments and fertilizers by composting of two-phase olive mill waste ("alperujo"). Journal of Cleaner Production, 26:48-55. doi: 10.1016/j.jclepro.2011.12.008

Usmani, Z., V. Kumar, R. Rani, P. Gupta, and A. Chandra, 2018. Changes in physico-chemical, microbiological and biochemical parameters during composting and vermicomposting of coal fly ash: a comparative study. International Journal of Environmental Science Technology, 16(8):4647-4664. doi: $10.1007 / \mathrm{s} 13762-018-1893-6$ 
Young, C.C., P.D. Rekha, and A.B. Arun, 2005. Chapter 3: What happens during composting? In Book: Compost production: A manual for Asian farmers. By: Zueng-Sang Chen and Cristina Bejosano-Gloria. Publisher: Taipei, Taiwan; Food and Fertilizer Technology Center for the Asian and Pacific Region, E148 - 10000363, E149 - 10000365, E5431 - 10010653.

Yu, G.H., Y.H. Luo, M.J. Wu, Z. Tang, D.Y. Liu, X.M. Yang, and Q.R. Shen, 2010. PARAFAC modeling of fluorescence excitation-emission spectra for rapid assessment of compost maturity. Bioresource Technology, 101:8244-8251, doi: 10.1016/j.biortech.2010.06.007. 